University of Wollongong

Research Online

Faculty of Social Sciences - Papers (Archive) Faculty of Arts, Social Sciences \& Humanities

2013

Ten years on: A follow-up review of ERP research in attention-deficit/ hyperactivity disorder

Stuart J. Johnstone

University of Wollongong, sjohnsto@uow.edu.au

Robert J. Barry

University of Wollongong, rbarry@uow.edu.au

Adam R. Clarke

University of Wollongong, aclarke@uow.edu.au

Follow this and additional works at: https://ro.uow.edu.au/sspapers

Part of the Education Commons, and the Social and Behavioral Sciences Commons

Research Online is the open access institutional repository for the University of Wollongong. For further information contact the UOW Library: research-pubs@uow.edu.au 


\title{
Ten years on: A follow-up review of ERP research in attention-deficit/hyperactivity disorder
}

\begin{abstract}
This article reviews the event-related potential (ERP) literature in relation to attention-deficit/hyperactivity disorder (AD/HD) over the years 2002-2012. ERP studies exploring various aspects of brain functioning in children and adolescents with $A D / H D$ are reviewed, with a focus on group effects and interpretations in the domains of attention, inhibitory control, performance monitoring, non-pharmacological treatments, and ERP/energetics interactions. There has been a distinct shift in research intensity over the past 10 years, with a large increase in ERP studies conducted in the areas of inhibitory control and performance monitoring. Overall, the research has identified a substantial number of ERP correlates of AD/HD. Robust differences from healthy controls have been reported in early orienting, inhibitory control, and errorprocessing components. These data offer potential to improve our understanding of the specific brain dysfunction(s) which contribute to the disorder. The literature would benefit from a more rigorous approach to clinical group composition and consideration of age effects, as well as increased emphasis on replication and extension studies using exacting participant, task, and analysis parameters.
\end{abstract}

\section{Keywords}

attention, deficit, up, hyperactivity, review, disorder, ten, years, follow, erp, research

\section{Disciplines}

Education | Social and Behavioral Sciences

\section{Publication Details}

Johnstone, S. J., Barry, R. J. \& Clarke, A. R. (2013). Ten years on: A follow-up review of ERP research in attention-deficit/hyperactivity disorder. Clinical Neurophysiology, 124 644-657. 


\section{Title}

Ten years on: A follow-up review of ERP research in Attention-Deficit/Hyperactivity Disorder

\section{Authors}

Stuart J. Johnstone ${ }^{1,2,3}$, Robert J. Barry ${ }^{1,2,3}$, Adam R. Clarke ${ }^{1,2,3}$

\section{Affiliations}

${ }^{1}$ School of Psychology, University of Wollongong, Wollongong, Australia

${ }^{2}$ Brain \& Behaviour Research Institute, University of Wollongong, Wollongong, Australia.

${ }^{3}$ Centre for Psychophysics, Psychophysiology, and Psychopharmacology, University of Wollongong, Wollongong, Australia.

\section{Corresponding author}

Stuart J. Johnstone

School of Psychology, University of Wollongong, Wollongong, NSW, Australia

Phone: +61 242214495

Fax: +61 242214163

Email: sjohnsto@uow.edu.au 


\title{
Highlights
}

- ERP studies from 2002 to 2012 exploring various aspects of brain functioning in children and adolescents with $\mathrm{AD} / \mathrm{HD}$ are reviewed.

- Research focus and intensity has been in the domains of attention, inhibitory control, performance monitoring, non-pharmacological treatments, and ERP/energetics interactions.

- Some consistent differences from healthy controls are emerging, but more emphasis on replication and extension studies is needed to increase the consistency and specificity of results.

\begin{abstract}
This article reviews the event-related potential (ERP) literature in relation to attentiondeficit/hyperactivity disorder (AD/HD) over the years 2002 to 2012. ERP studies exploring various aspects of brain functioning in children and adolescents with $\mathrm{AD} / \mathrm{HD}$ are examined, with a focus on group effects and interpretations in the domains of attention, inhibitory control, performance monitoring, non-pharmacological treatments, and ERP/energetics interactions. There has been a distinct shift in research intensity over the past 10 years, with a large increase in ERP studies conducted in the areas of inhibitory control and performance monitoring. Overall, the research has identified a substantial number of ERP correlates of AD/HD. Robust differences from healthy controls have been reported in early orienting, inhibitory control, and error-processing components. These data offer potential to improve our understanding of the specific brain dysfunction(s) which contribute to the disorder. The literature would benefit from a more rigorous approach to clinical group composition and consideration of age effects, as well as increased emphasis on replication and extension studies using exacting participant, task, and analysis parameters.
\end{abstract}

\section{Keywords}

Attention-deficit/hyperactivity disorder; Electrophysiology; Event-related potentials 


\section{Introduction}

This paper reviews the field of event-related potentials (ERPs) in AttentionDeficit/Hyperactivity Disorder (AD/HD) over the period 2002 to 2012, and follows our previous review article published some 10 years ago (Barry, Johnstone, Clarke, 2003b) and a companion paper focussed on EEG research in this group (Barry, Clarke, Johnstone, 2003a). The qualitative review presented here focuses on studies measuring ERPs in children and adolescents with AD/HD during performance of perceptual/cognitive tasks. Papers were selected from the results of a search using the Ovid PsycINFO database using the terms "event related potential”, "ERP”, “attention deficit hyperactivity disorder”, “ADHD”, and “AD/HD”, with exclusion of studies focussing on adults with $\mathrm{AD} / \mathrm{HD}$, those that primarily sought to examine the effect of medication, and those that used other functional measurement technologies such as PET or fMRI. Papers that were not identified in this search, but came to light during the review process were also included if they met the above criteria. While all efforts were made to ensure that all of the AD/HD-ERP papers published during 2002 to 2012 are included, it remains possible that some are not reviewed here.

The current Diagnostic and Statistical Manual (DSM-IV) outlines three subtypes of AD/HD: the combined type (AD/HDcom), the predominantly inattentive type (AD/HDin), and the predominantly hyperactive/impulsive type (AD/HDhyp) (American Psychiatric Association, 2000). These subtypes are based on different clusters of symptoms from within the two core symptom domains of Inattention and Hyperactivity/Impulsivity. Specifically, the diagnostic criteria for $\mathrm{AD} / \mathrm{HDcom}$ require evidence of significant impairment across both domains, while AD/HDin and $\mathrm{AD} /$ HDhyp require evidence of significant impairment in only one domain, i.e. Inattention or Hyperactivity/Impulsivity, respectively. In population studies diagnoses of AD/HDhyp are relatively rare, with a prevalence rate of only $0.2 \%$ in Australia (Gomez et al., 1999), compared to $1.6 \%$ and $0.6 \%$ for the $\mathrm{AD} / \mathrm{HDin}$ and $\mathrm{AD} / \mathrm{HDcom}$ subtypes respectively. Indeed, this is reflected in the papers reviewed here, with only two studies exclusively examining children with this subtype (Gomarus et al., 2009; Zhang et al., 2009), and a few including a small proportion of children with AD/HDhyp in mixed subtype samples (e.g. Alexander et al., 2008; Shen et al., 2011). Note that within clinic populations, the $\mathrm{AD} / \mathrm{HDcom}$ subtype is two to four times more prevalent than the other two subtypes (Wolraich et al., 1996).

ERPs allow researchers to gain insight into the spatial and temporal characteristics of neural activity related to the component processes of behaviours such as selective attention, response selection, inhibitory control and performance monitoring. By providing a 'window' into the sensory and cognitive processes, ERPs provide a level of analysis additional to overt behavioural and task performance measures, allowing consideration of typical (e.g. developmental) and atypical processes (e.g. clinical compared to healthy groups).

\section{Progress since last review}


Since the 2003 review, there have been several shifts in research focus and intensity in the ERP area, with a move away from studies examining aspects of attention, and a large increase in the investigation of various forms of inhibitory control and performance monitoring. Our previous review, which has been well cited in the literature, made suggestions as to future directions for this research area, including more (1) focus on identifiable subtypes of $\mathrm{AD} / \mathrm{HD}$ rather than using mixed groups, (2) consideration of co-morbidity in AD/HD using an optimal four-group design, (3) exploration of links between EEG and ERP differences, (4) consideration of the relationships between early and subsequent ERP component differences, and (5) focus on the use of EEG/ERP in diagnosis (Barry et al., 2003b). As will be detailed below, some progress has been made in these areas.

We identified participant age and AD/HD subtype as crucial factors when considering ERP component differences and topography in participants with or without AD/HD. Many of the studies reviewed here have appropriately used a small age-range, with child participants aged approximately 7 to 12 years (e.g. Overtoom et al., 2002), or similarly, adolescent participants aged approximately 13 to 18 years (e.g. Wild-Wall et al., 2009). Others have appropriately used a broad age-range and included age as a grouping variable in their statistical analyses (e.g. Keage et al., 2006). However, many instances of less than ideal age-ranges can also be identified, with children and young adolescents grouped together (e.g. Johnstone et al., 2007a; Groom et al., 2010b), or broad ranges with age not used as a grouping factor in the analysis (e.g. Williams et al., 2008). See the "Age range” column of Tables 1-6 for the relevant information from each study reviewed - greyed cells indicate optimal consideration of the age factor.

There has been consistency in the diagnostic criteria for AD/HD and its subtypes for the past 18 years. Despite this, and reports of substantial differences between the AD/HD subtypes in task performance and ERPs (e.g. Johnstone, et al., 2007; Johnstone, Barry, \& Dimoska, 2003) and academic and social outcomes (Wolraich et al., 1996), many studies have used mixed samples dominated by the AD/HDcom subtype (e.g. Kratz et al., 2011), while others appropriately compared subtype groups (e.g. Burgio-Murphy et al., 2007). Another issue is the use of ICD-10 (which does not make the distinction between subtypes) for diagnosis, often with the diagnosis of hyperkinetic disorder (HD) reported as “concordant with DSM-IV AD/HD combined type” (e.g. Albrecht et al., 2005). Some studies use neither of these diagnostic criteria, but rather infer a diagnosis from diagnostic interviews such as DISC-IV (e.g. Wiersema et al., 2006), or questionnaire responses (e.g. Spronk et al., 2008). Surprisingly, other diagnostic issues continue in the literature, such as using old diagnostic criteria, e.g. DSM-III-R, in which subtypes were not distinguished (e.g. Doehnert et al., 2010), using the current criteria but not specifying the subtype (e.g. Gumenyuk et al., 2005), or reporting AD/HD subtypes but not specifying the diagnostic criteria (e.g. Holroyd et al., 2008). See the "AD/HD type" column of Tables 1-6 for group composition information for each study reviewed here. While the authors acknowledge the inherent limitations of psychiatric classification systems, and that $\mathrm{AD} / \mathrm{HD}$ is an aetiologically and biologically heterogeneous disorder, a systematic approach 
to group composition in regard to $\mathrm{AD} / \mathrm{HD}$ subtypes would seem essential to increase the consistency and specificity of results.

\section{Summaries of results and interpretations}

The majority of the papers reviewed here fall into one of five main categories: attention, inhibitory control, performance monitoring, intervention effects, and ERP/energetic interactions. The reviewed papers are grouped according to the primary focus of the study, although some examined are relevant to multiple categories; these are described only in the Table of the primary category. As ERP component characteristics (such as timing, amplitude and topography) are highly dependent on the task performed and the modality of stimulus presentation, studies within each category are grouped, where possible, according to these two primary factors. The focus of the summaries below is the clinical group, with an emphasis on significant ERP differences (typically as compared to healthy controls, unless otherwise indicated), and interpretations.

\subsection{Attention}

Several studies examined attention as a core construct, using selective attention, continuous performance tasks (CPTs), oddball, and distraction tasks. The proportion of studies in this domain was reduced from our previous review (Barry et al., 2003b). Details of these studies are provided in Table 1.

-- Table 1 about here -

Selective attention tasks typically involve the detection of infrequent (e.g. 25\% of trials) targets amongst standard stimuli while focussing on one stimulus parameter and ignoring another (e.g. colour vs. shape in a visual task; ear of presentation for an auditory task). In a selective attention task, children with $\mathrm{AD} / \mathrm{HDcom}$ showed attenuated frontal selection positivity (FSP) indicating a problem with selection between visual stimuli based on salient surface features, as well as a target P3b difference indicating problems with selection based on more complex semantic information; the N2 and posterior selection negativity were typical (van der Stelt et al., 2001). Similarly, an FSP difference was interpreted to indicate an early visual filtering deficit in children with DSM-III-R defined ADHD, with no differences reported for later executive or control processes (Jonkman et al., 2004).

In a typical CPT task, participants respond to a target stimulus (e.g. when the letter $\mathrm{X}$ is preceded by a pre-defined cue stimulus such as the letter A), and inhibit responses to cued non-targets (e.g. when letters other than $\mathrm{X}$ follow the $\mathrm{A}$ ), with cues requiring orienting and targets requiring selection for action. In a study of children diagnosed with ICD-10 HD, Brandeis et al. (2002) reported enhanced cue-N1 and attenuated cue-P3a/P3b, interpreted as overly strong initial orienting to 
cues, and subsequent issues with attention resource allocation, respectively. Children with $\mathrm{AD} / \mathrm{HDcom}$ showed differences in P3 indicative of problems with cue orienting, and subsequent CNV differences indicating inefficient preparation for the upcoming stimulus, effects that were not present for an Oppositional Defiant Disorder (ODD) or co-morbid AD/HDcom and ODD group (Banaschewski et al., 2003). During a CPT, children with AD/HDcom were reported to show reduced frontal N1 and N2 amplitudes and parietal P2 and P3 amplitudes to target stimuli, indicating diminished evaluative and processing capabilities (Lawrence et al., 2005). Children aged 5-7 with $\mathrm{AD} / \mathrm{HD}$ characteristics were reported to show an atypical Go-P3 effect suggesting deficient attentional resource allocation, and a difference in cue-P3 indicating impaired orienting (Spronk et al., 2008). In a rare longitudinal study that examined attention and inhibitory processing in DSM-III-R diagnosed ADHD participants over 2.5 years (mean age 10.8 years at time 1), reduced P3a and P3b to cue stimuli indicated persistent impairment in attention orienting and resource allocation (Doehnert et al., 2010; see Table 2).

The typical oddball task involves making a button-press response to indicate detection of an infrequent (e.g. 25\% of trials) target stimulus amongst non-target stimuli. In an oddball study examining the effects of stimulus probability/sequencing in various $\mathrm{AD} / \mathrm{HD}$ subtypes with and without reading or math disorder, children with $\mathrm{AD} / \mathrm{HDcom}$ and $\mathrm{AD} / \mathrm{HDin}$ did not show the expected increase in P3b latency and N2 and P3b amplitude to "novel” sequence variations, with few differences in ERPs between the subgroups in the easy equiprobable "oddball” task (Klorman et al., 2002). Brown et al. (2005) examined children with AD/HDin using an oddball task with visual nontarget and auditory target stimuli, and reported reduced N1, P2 and P3 amplitude to both stimulus types, interpreted as a general deficit in stimulus registration, facilitation and processing. AD/HDcom and $\mathrm{AD} / \mathrm{HDin}$ subtypes were subsequently compared in this multi-modal oddball task, with similar but more extreme differences reported for AD/HDcom, and the reduced P3 amplitude for both groups seen as indicating that a deficit in discrimination and classification of all stimuli is a core feature of AD/HD (Barry et al., 2006).

In a study of adolescents with co-morbid ADHD and conduct disorder (CD) using an auditory single-stimulus "oddball” task (i.e. a standard oddball task in which the non-target stimuli are not presented), it was shown that the clinical group had delayed P2, N2 and P3 latency, and reduced P3 amplitude, interpreted as a deficit in automatic processing of passive stimuli (Du et al., 2006). Lopez et al. (2006) used a spatial oddball task to examine distraction, and reported that the presence of P3 to spatially-distant task-irrelevant stimuli for the AD/HDcom group (but not controls) indicated inappropriate late attention allocation, after intact early spatial attention filtering indicated by the N1. Using an auditory oddball task, Yorbik et al. (2008) examined the effect of plasma zinc level on information processing in children with and without $\mathrm{AD} / \mathrm{HD}$, with reduced amplitude and longer latency P3 interpreted in terms of deficient working memory updating. A zinc-deficient AD/HD group showed an earlier N2 component than controls, suggesting an unique effect on inhibition 
processing. Barry et al. (2009) used a multi-modal oddball to investigate attention processing in children with AD/HDcom who had excess beta activity in their EEG (a previously-reported minority group within this subtype), and found that this group was more typical than the AD/HDcom group without excess beta; they did not show the reduced P2 and P3 seen in the latter group, indicating intact discrimination and categorisation processing. Senderecka et al. (2012a) examined children with AD/HDcom during an auditory oddball task and reported increased P2 and reduced N2 to target and non-target stimuli, seen to indicate an orienting deficit and issues with stimulus discrimination impairment, respectively. Further, reduced target P3 was interpreted as indicating a deficit in attention allocation and stimulus evaluation (Senderecka et al., 2012a).

Two studies used dual-modality tasks with a primary visual task and auditory distracter stimuli. A small sample of children with AD/HD (subtype not specified) showed reduced early P3a and late negativity to the auditory distracter, interpreted as abnormal involuntary attention and reorienting attention respectively (Gumenyuk et al., 2005), although note that the auditory ERPs were partially overlapped by the response to the subsequent visual stimulus. van Mourik et al. (2007) reported an enhanced early P3a (which might be better labelled a P2 given its timing) that was interpreted as indicating increased orienting to both standard and novel stimuli in a mixed subtype $\mathrm{AD} / \mathrm{HD}$ group. A frontal late negative component that did not differ between groups was interpreted as indicative of intact re-orienting after distraction (van Mourik et al., 2007). In a different task that also examined distraction, children and adolescents with AD/HDcom and AD/HDin showed atypical P3a to novel distracter stimuli during memory processing, albeit each in slightly different ways, indicating atypical attention switching following novel events (Keage et al., 2006).

\subsection{Inhibitory control}

Executive functions are described as mental control processes that facilitate self-control (Geurts et al., 2005). Inhibition is one of the executive function domains and has been investigated using tasks such as the Stop-signal, Go/Nogo and CPT. The number of papers in this category has increased dramatically since the last review. Details of these studies are provided in Table 2.

\section{-- Table 2 about here -}

\subsubsection{Stop-signal}

In the Stop-signal task participants perform a primary visual binary-choice RT task, and on a proportion of trials (e.g. 25\%) are instructed to inhibit that response upon the presentation of a Stop stimulus (an auditory or visual stimulus), which can occur at any time at or after the onset of the primary task stimulus.

Several studies used visual primary and auditory stop signals. Overtoom et al. (2002) reported a reduced frontal inhibition-related positivity in children with DSM-III-R defined ADHD, 
interpreted as reflecting weaker motor inhibition. Further, a posterior positivity showed increased amplitude on successful compared to failed inhibition trials, an effect not seen in controls, and interpreted in terms of the error positivity ("Pe") and poorer evaluation of incorrect responses in ADHD (Overtoom et al., 2002). In a similar task, atypical early sensory processing of stop signals was suggested by the N1 and P2 components, with reduced N2 on successful inhibition trials seen as an indication of weak activation of the inhibition process (Dimoska et al., 2003). Our group examined the $\mathrm{AD} / \mathrm{HDcom}$ and $\mathrm{AD} / \mathrm{HDin}$ subtypes, with $\mathrm{N} 2$ and P3 differences indicating inhibitory processing problems for $\mathrm{AD} / \mathrm{HDcom}$ and a unique pattern of differences that indicated atypical sensory registration (increased N1) and problems with inhibition processing (reduced N2 and increased P3) for AD/HDin (Johnstone et al., 2007a). Senderecka et al. (2012b) reported a reduced successful> unsuccessful effect for P2 (indicating an orienting deficit) and P3 (indicating cognitive control problems) in children with AD/HDcom, and while the unsuccessful >successful N2 effect did not differ between groups, the stop-N2 was larger and later in children with AD/HDcom; interpreted as a response inhibition issue.

Several studies used visual primary and stop signals. Albrecht et al. (2005) reported reduced $\mathrm{N} 2$ in the right-frontal area to visual stop signals in children with $\mathrm{AD} / \mathrm{HDcom}$ or ODD/CD, but not in a co-morbid group of $\mathrm{AD} / \mathrm{HDcom}+\mathrm{ODD} / \mathrm{CD}$, with this effect interpreted as a deficit in response inhibition. In a study mainly focussed on error processing it was reported that children with $\mathrm{AD} / \mathrm{HDcom}$ showed inefficient successful implementation of response inhibition with a reduced successful>failed P3a effect (Liotti et al., 2005; see Table 3). Liotti et al. (2007) also reported that children with $\mathrm{AD} / \mathrm{HDcom}$ had reduced N2, with the scalp location of the difference dependent on successful vs. failed inhibition; further, they did not show the success-specific N2 enhancement seen in controls, indicating problems with the triggering of response inhibition. Additionally, a Nogo-P3 reduction was interpreted as a deficit in cognitive control and performance monitoring (Liotti et al., 2007). A subsequent study showed that the $\mathrm{N} 2$ effect was unique to $A D / H D c o m$ and not present in children with reading disorder, while the P3 effect was present in both groups (Liotti et al., 2009). In a study with a mixed subtype $\mathrm{AD} / \mathrm{HD}$ group, reduced $\mathrm{P} 1$ to stop signals was seen to reflect less efficient early attention (Shen et al., 2011); there was no N2 difference reported, contrary to other studies reviewed above.

\subsubsection{Go/Nogo and CPT}

The Go/Nogo task usually involves the inhibition or suppression of a pre-potent response to a low probability (e.g. 20\% of trials) "Nogo" stimulus in the context of a two-choice reaction time task with a button-press response required to a frequently presented (e.g. 80\% of trials) "Go" stimulus. In the Go/Nogo and CPT tasks, participants have to suppress or withhold a prepared, but not yet initiated, response. This is different form of inhibitory control than in the Stop-signal task, which involves stopping an already-activated response (Johnstone et al., 2007b). 
Using an auditory cued Go/Nogo task, children with AD/HDcom showed early- and underactivation of P2 after earlier differences in information extraction at N1 to Go/Nogo stimuli, as well as an increased N2 Nogo>Go effect (Smith et al., 2004). This suggested an intact response inhibition mechanism because of increased inhibitory effort after the earlier differences. Broyd et al. (2005) used an auditory cued Go/Nogo task and reported that younger children with AD/HD (9.9 years) did not show an expected Nogo>Go N2 effect, while an older clinical group (12.8 years) showed a Nogo $>$ Go N2 effect that was similar to younger controls. Earlier N1 differences indicated that focusing of attention increased with age in controls, but not in children with AD/HD (Broyd et al., 2005).

In a visual Go/Nogo task, our group showed that task parameters, such as a fixed- versus variable-duration warning period, can influence performance and ERPs, with AD/HDcom showing reduced early inhibition processes (P2), and indications of compensatory activation of later processes by a more anterior P3b linked to the frontal inhibition process (Johnstone et al., 2009). While Wiersema et al. (2006; see Table 5) mainly focussed on examining the mediating influence of energetic factors such as activation, arousal and effort on task performance (see section 3.5 for further information), they also reported that inhibition processing problems were indicated by a reduced visual Nogo N2 in children with co-morbid AD/HD and CD/ODD, but not children with AD/HD alone. Taking a slightly different analytic approach, self-reported measures of effortful-control persistence as well as impulsivity were found to be positively correlated with Nogo P3 but not N2 amplitude, while attention-focussing was correlated also with Nogo P3 but not N2; further, attentionshifting was negatively correlated with $\mathrm{N} 2$ but not $\mathrm{P} 3$ amplitude in a mixed-subtype AD/HD group and controls (Wiersema and Roeyers, 2009). Groom et al. (2008) reported that adolescents with AD/HDcom showed reduced N2 in a Go/Nogo but not Oddball task, and no P3 differences in either task, suggesting persistence of inhibition deficits into adolescence. Groom et al. (2010b) examined the influence of motivation on Go/Nogo task performance, and reported that N2 and P3 were larger when the incentive to inhibit was increased for all participants, and children with AD/HDcom showed reduced P3 (indicating decreased attention) to the task relevant stimuli regardless of incentives (Groom et al., 2010b).

The CPT task allows consideration of a range of processes, due to its multifaceted nature. In the inhibitory context, response activation is required to cued target or "Go" stimuli, with response inhibition elicited by cued non-targets or "Nogo" stimuli; there is usually an equal and low probability presentation of each these two stimulus types (often, 10\%) amongst the majority of uncued stimuli. In a CPT study focussing on motor response execution and inhibition, intact N2 but attenuated P3b in $\mathrm{AD} / \mathrm{HDcom}$ was taken to indicate a lower degree of controlled stimulus processing during response inhibition (Banaschewski et al., 2004). Children with ADHDcom have been reported to have problems with response preparation as indicated by the CNV to cue stimuli, and deficient response inhibition as indicated by Nogo-P3 (Valko et al., 2009). As outlined in the attention section, during a 
CPT task young children with ADHD characteristics did not show differences in ERP components related to conflict (Nogo N2) or inhibition (Nogo P3) processing (Spronk et al., 2008; see Table 1). Longitudinal data from DSM-III-R diagnosed ADHD participants over 2.5 years (mean age 10.8 years at time 1) showed CNV differences that suggested a persistent preparation deficit, as well as Nogo P3 differences suggesting persistent inhibitory control problems (Doehnert et al., 2010).

\subsubsection{Flanker task}

The flanker task provides a measure of another facet of inhibition processing, namely, interference control. Participants respond with a button-press to the direction of a target arrow and ignore distracter stimuli flanking the target, which may be congruent, incongruent, or neutral with regard to the target. Jonkman et al. (2007) reported that children with DSM-III-R defined ADHD and controls showed larger N2 to correct compared to incorrect incongruent trials, with a trend towards larger N2 overall for ADHD indicating enhanced sensitivity to conflict caused by the flanker stimuli. An N2 amplitude enhancement to incongruent compared with congruent stimuli has been reported to be reduced in children with AD/HDcom, but not unaffected siblings, indicating a conflict monitoring deficiency (Albrecht et al., 2008). In our study examining both Go/Nogo (reported above) and Flanker tasks, we reported that conflict/inhibition processing problems were indicated by a reduced N2 and P3 amplitude to incongruent flankers in children with AD/HDcom, following earlier differences at N1 and P2 (Johnstone et al., 2009). The N2 and P3 differences were also seen in a subsequent study mainly examining energetic factors (Johnstone et al., 2010b; see Table 5). During a hybrid Flanker-Nogo task, adolescents with AD/HDcom showed a generally reduced N2, indicating a problem with controlled response selection, and no N2 enhancement for Nogo compared to incongruent trials, indicating a further problem with controlled response suppression (Wild-Wall et al., 2009). In a study using the Attention Network Test, which is very similar to a cued Flanker task, children with $\mathrm{AD} / \mathrm{HDcom}$ and $\mathrm{AD} / \mathrm{HDin}$ both showed reduced attention to cues (reduced cue-P3) as well as reduced target P3, suggesting a general deficit in attentional resource allocation (Kratz et al., 2011).

\subsubsection{Other inhibition tasks}

During an auditory Stroop task, children in a mixed-subtype AD/HD group showed a reduced incongruent>congruent effect in $\mathrm{P} 3 \mathrm{~b}$, indicating a failure to allocate resources appropriately when conflicting information was present (van Mourik et al., 2010).

\subsection{Performance monitoring}

Papers reviewed in this section relate to the processing of errors and performance feedback. These processes play a role in monitoring or evaluation, and are differentially activated when an outcome is unexpected, incorrect, unfavourable, or in conflict with goals (van Meel et al., 2011). 
There were very few papers in this category in the last review. Details of these studies are provided in Table 3.

-- Table 3 about here -

\subsubsection{Error processing}

Two main components are seen in response-locked ERPs to errors. These are known as the error-related negativity (ERN, or Ne) and the error positivity (Pe), with the former thought to represent error detection, and the latter, error evaluation. Error processing has been examined during Stop-Signal, Go/Nogo, Flanker, Oddball and learning tasks.

Examining errors during a Stop Signal task, a reduced ERN in children with AD/HDcom was interpreted as evidence of impaired error monitoring (detection and correction) by Liotti et al. (2005). In a mixed-subtype group of children with AD/HD who completed a Stop-signal task, normal ERN and reduced Pe were reported, and interpreted as indicating intact early error monitoring but problems in the awareness and conscious evaluation of errors (Shen et al., 2011; see Table 2). Both ERN and Pe were found to be reduced in children with AD/HDcom during a Stop-signal task, interpreted as indicating issues with error detection and evaluation of the error (Senderecka et al., 2012b; see Table 2).

Children with AD/HDcom showed smaller Pe following errors in a Go/Nogo and a two stimulus reaction time task (warning stimulus presented before imperative stimulus), taken to indicate an impairment in processing/evaluation of the error event, but not detection of the error, as ERN did not show group effects (Wiersema et al., 2005a). Zhang et al. (2009) examined error processing during a Go/Nogo task in a rare study of children with AD/HDhyp, and reported typical ERN latency and amplitude, but a reduced parietal Pe indicating weaker processing of error recognition. In a traditional Go/Nogo task, adolescents with AD/HDcom have shown no differences in ERN and a trend level effect for Pe (Groom et al., 2010a). Intact error detection, as indicated by ERN (Ne), and deficient error awareness/evaluation, as indicated by reduced Pe, were reported in a study using a demanding Go/Nogo task in children with AD/HD (subtype not specified) (Van De Voorde et al., 2010).

In children with DSM-III-R defined ADHD who completed a Flanker task, both ERN and Pe were reported to be larger on error than correct response trials as expected, with reduced Pe indicating reduced error awareness in the clinical group (Jonkman et al., 2007; see Table 2). In a mixed-subtype $\mathrm{AD} / \mathrm{HD}$ group with a large proportion of participants with comorbid ODD, reduced ERN after errors in a Flanker task was interpreted as a performance monitoring deficit (van Meel et al., 2007). Following errors in a flanker task, a broad age-range AD/HDcom group displayed reduced ERN but no differences in Pe, indicating a deficit in initial error processing (Albrecht et al., 2008; see Table 2). 
In a hybrid Flanker/Nogo task there were no group differences in ERN or early and late Pe to errors in adolescents with AD/HDcom (Wild-Wall et al., 2009; see Table 2).

During a visual oddball task children with $\mathrm{AD} / \mathrm{HDcom}$, but not AD/HDin, unexpectedly showed larger ERN than controls, suggesting that they were more sensitive to the detection of errors, or more emotionally reactive to errors, in this simple task; Pe amplitude did not show group effects for either subtype (Burgio-Murphy et al., 2007). During a feedback-based learning task, medicationnaive children with $\mathrm{AD} / \mathrm{HDcom}$ showed decreased ERN and Pe to errors, suggesting problems with early detection and later awareness of errors (Groen et al., 2008).

Some of the papers in this section were included in a previous review of error processing in $\mathrm{AD} / \mathrm{HD}$ (Shiels and Hawk, 2010). In this research area, the need for tighter control of parameters such as task difficulty (as ERN differences may only be present when high levels of cognitive control are required), analysis type, and groups, have been suggested (Wild-Wall et al., 2009; van Meel et al., 2011), with the additional careful consideration of age grouping also being warranted.

\subsubsection{Feedback processing}

ERPs have also been used to examine the effect of delivery of performance feedback indicating whether the previous response was correct or incorrect, with waveforms stimulus-locked to the feedback. Two of the studies from 3.3.1 also examined feedback-related activity. Children with ADHD were reported to show an increased feedback-related negativity (FRN) in the 300-500 ms range, suggesting over-activation of evaluative processes related to unfavourable outcomes during a guessing paradigm (van Meel et al., 2005). During a feedback-based learning task, medication-naive children with $\mathrm{AD} / \mathrm{HDcom}$ showed a reduced negative>positive feedback effect for $\mathrm{P} 2 \mathrm{a}$, indicating a reduced attention reaction to these motivationally relevant feedback stimuli; further, pre-feedback activity did not show group effects in anticipating negative feedback, but the clinical group showed increased activity preceding positive feedback (Groen et al., 2008).

Several studies have specifically focussed on feedback-related activity. Holroyd et al. (2008) reported that children with $\mathrm{AD} / \mathrm{HDcom}$ showed an atypical time-on-task effect in a virtual maze guessing task, with larger feedback ERN amplitude in the second than first half of the task, due mainly to a physical monetary reward at the half-way point and subsequent increased task engagement. In a time estimation task with visual feedback, children with AD/HDcom did not show differential modulation of FRN in reward and punishment conditions, or late positive potential (LPP) enhancement to punishment, indicating less effective monitoring of feedback and subsequent insufficient attention to feedback (van Meel et al., 2011).

\subsection{Examining the effects of non-pharmacological interventions}


Given their sensitivity to variations in perceptual and cognitive factors, ERPs have been used to measure the effectiveness of a range of non-pharmacological treatments. There has been an increase in research in this area since the last review. Details of these studies are provided in Table 4.

-- Table 4 about here -

Heinrich et al. (2004) reported that, as well as behavioural improvements, slow cortical potential (SCP) neurofeedback training resulted in a larger CNV during a CPT task post-training, compared to a wait-list group, interpreted as an indication of improved resource allocation and selfregulatory capacity. Doehnert et al. (2008) reported no CNV differences between an SCP neurofeedback group and a 'group therapy' control group, although participants who performed well at training had higher CNV amplitude. Wangler et al. (2010) showed that SCP neurofeedback training resulted in increased CNV during a CPT task, and that the increase was related to the degree of behavioural improvements, an effect that was not found after theta/beta neurofeedback; these results were interpreted as showing a specific effect of SCP training on regulation of cortical excitability and energetic resources. The SCP and theta/beta training protocols both led to increased cue-P3, indicating better allocation of attention resources to salient stimuli (Wangler et al., 2010).

Neurofeedback training of relative beta EEG activity has been shown to result in enhanced Nogo-P3, but no changes in earlier ERP components, in patients with good compared to bad training outcomes (Kropotov et al., 2005). Along with behavioural improvements, a non-specific increase in $\mathrm{N} 1$ and a specific increase in N2 for those in a variable-difficulty training condition have been reported following combined working memory and impulse-control training in children with AD/HDcom, taken to indicate improved early attention and inhibition processing (Johnstone et al., 2010a).

\subsection{Interaction with energetic factors}

ERPs have been used to investigate the influence that energetic factors such as activation, arousal, and effort have on performance of tasks involving response inhibition, in line with predictions of the Cognitive Energetic Model of AD/HD (Sergeant, 2000). Based on the work of Sanders (1983), this model posits that the efficiency of informational processing is the result of the interplay between computational processes (including encoding, search, decision and motor organisation) energetic factors and an executive function. The energetic state of the individual mediates the efficiency of the computational processes. Tasks that are highly demanding require a great amount of energy to perform successfully, in which case the individual is not likely to be in the appropriate energetic state. The individual must then increase effort to mobilise energetic resources in order to equilibrate their energetic state with the energetic requirements of the task. 
In most of these studies event-rate (i.e. the inter-stimulus interval) is used to vary effort/arousal, with adjustment necessary to cope with a fast rate that induces over-arousal and fast, inaccurate responding, and a slow event-rate that induces under-arousal resulting in slow, inaccurate responding. There has been an increase in research in this area since the last review. Details of these studies are provided in Table 5.

-- Table 5 about here -

In a study using a visual Go/Nogo task, children with $\mathrm{AD} / \mathrm{HDcom}$ showed slow and variable responding and a reduced P3 amplitude in the slow event-rate condition, seen as indicating a lack of adjustment of effort required to meet the task demands (Wiersema et al., 2005b). In a study with fast and slow presentation of a Go/Nogo task, the relationship between P3 amplitude and Go RT indicated poor effort allocation in the slow condition, with a reduced Nogo-N2 in the fast condition for children with co-morbid AD/HD and ODD, but not an AD/HD-alone group (Wiersema et al., 2006). Using fast, medium and slow event-rates in a cued Go/Nogo task, Benikos and Johnstone (2009) reported a reduced P2 across event-rates, reflecting inefficient suppression of sensory activation, and reduced Nogo-P3 in the fast condition, linked to inhibition problems, in AD/HDcom. Interestingly, event-rate specific group differences for N1 and N2 to warning stimuli, and reduced CNV, suggest that effort/arousal influences attention to task-irrelevant stimuli and preparatory processes (Benikos and Johnstone, 2009). When examining event-rate effects on interference control during a flanker task, children with $\mathrm{AD} / \mathrm{HDcom}$ made more omission errors at the fast and slow rates, with no differences in the incongruent>neutral N2 and P3 effects, indicating intact conflict processing and effort allocation at each event-rate in this task (Johnstone and Galletta, in press).

Stimulus degradation has also been used to manipulate effort in the flanker task, and it was reported that the N2a reduction in children with $\mathrm{AD} / \mathrm{HD}$ was greater when more effort was required (Johnstone et al., 2010b), in line with the cognitive energetic model.

\subsection{Studies from a variety of other areas}

The studies reviewed in the following section do not comfortably sit within the five main categories of studies reviewed above, but cover a range of areas in which ERPs have been utilised effectively. Study details are provided in Table 6.

-- Table 6 about here -

\subsubsection{Time-frequency}

Several studies have investigated event-related changes in EEG oscillations, which are superimposed in time domain ERPs, and are thought to provide clearer differentiation of specific 
stages of perceptual and cognitive processes that occur in different frequency channels (Basar-Eroglu et al., 1992). Several studies have focussed on event-related delta activity. Johnstone et al. (2003) reported that ERPs in the $0.01-2 \mathrm{~Hz}$ frequency range revealed atypical early frontal activation and later inhibition of posterior areas in $\mathrm{AD} / \mathrm{HDcom}$ that was not present in the $\mathrm{AD} / \mathrm{HDin}$ subtype, and was not clear in the original 0.01-12 Hz waveforms. After accounting for these differences, traditional components such as N2 and P3b for both subtypes differed from controls, interpreted as reflective of similar discrimination/memory issues in both subtypes, independent of differences in regional inhibition/activation. Focusing on activity in the 0.5-1.5 Hz range, Alexander et al. (2008) reported that decreased activity was present in selective and sustained attention conditions in the auditory and visual modalities, in a mixed-subtype sample of children and adolescents with AD/HD.

Yordanova et al. (2006) examined event-related theta activity in children with DSM-III-R defined ADHD, and reported that an early theta response (0-200 ms), functionally linked to a working memory trace of target stimulus characteristics, did not differ from controls, while a later theta response (200-450 ms), evoked only to task irrelevant stimuli, was larger in ADHD and explained by the greater spontaneous theta EEG in that group.

Event-related gamma activity has been investigated in two studies. Lenz et al. (2008) looked at a mixed subtype group of children/adolescents with $\mathrm{AD} / \mathrm{HD}$ and reported that controls showed a positive correlation of evoked gamma activity during the encoding phase with subsequent recognition performance, while the $\mathrm{AD} / \mathrm{HD}$ group showed over-activation of gamma that was not related to subsequent performance; this was interpreted as inappropriate unspecific activation of processing resources in $\mathrm{AD} / \mathrm{HD}$. A subsequent study, which also used a mixed subtype sample spanning the child/adolescent age range, reported that event-related gamma activity was larger for controls when the stimulus matched information stored in long-term memory, while there were no differences between known and unknown items for the AD/HD group, indicating an issue with stimulus classification based on memory and flow-on problems with attentional resource allocation (Lenz et al., 2010).

\subsubsection{Memory tasks}

In a rare study of the AD/HDhyp subtype, Gomarus et al. (2009) reported no group differences in ERPs elicited during the storage phase of a recognition memory task, or the frontal selection positivity during the search phase, while differences were present in the later search-related negativity, indicating impaired controlled working memory processing. In a study of memory with an incidental encoding phase and a recognition memory task, a mixed subtype AD/HD group showed adequate preparatory negativity after cueing, and the expected remembered $>$ forgotten P3 effect, but the reduced P3 suggested an AD/HD deficit in encoding of less-salient neutral stimuli (Krauel et al., 2009). 


\subsubsection{ERPs in diagnosis}

ERP amplitude/latency and performance data from an auditory oddball task were shown to classify $\mathrm{AD} / \mathrm{HD}$ (both major subtypes) versus healthy controls with $73 \%$ accuracy in children; buttonpress reaction time, N1, P2, P3 latency to standard stimuli, and P3 amplitude to target and standard stimuli contributed most to classification. Accuracy was lower (59\%) in adolescents, with P3 amplitude and latency to target and standard stimuli contributing most to classification (Smith et al., 2003).

\subsubsection{Preparation/motor processes}

Using a CPT task, Banaschewski (2008) investigated the effect of stimulus context on motor preparatory activity, and showed that CNV in the cue-target interval was reduced in children with $\mathrm{AD} / \mathrm{HDcom}$ regardless of the Go/Nogo/neutral context; this was seen as a failure of the executive control system in organising preparation. Context-independent over-activation of the ipsilateral motor area in $\mathrm{AD} / \mathrm{HDcom}$ indicated reduced suppression of functionally irrelevant motor areas (Banaschewski et al., 2008).

\subsubsection{Emotional processes}

When viewing faces displaying various emotions, a broad age-range sample of participants with AD/HD showed reduced occipital P120, indicating impaired early perceptual analysis of emotion, with flow-on differences in N170 related to encoding of emotional input, and a reduced P300 indicating problems with contextual processing (Williams et al., 2008).

\section{Summary and conclusions}

Summarising the outcomes of research within each of the three main process categories (attention, inhibition, and performance monitoring) is very difficult, as no two studies use the same participant, task, and analysis parameters. Despite this limitation, some reasonably consistent effects may be observed. In the attention domain, selective attention and CPT tasks indicate issues with orienting to cues and selection/resource allocation processes to target stimuli via P3, with oddball studies indicated stimulus discrimination and evaluation problems reflected by N2 and P3, and distraction tasks indicating attention switching/orienting problems. When considering inhibitory control tasks, Stop-signal studies have indicated deficits in response inhibition via N2 and P3 effects that were often preceded by differences in earlier components (e.g. N1 and P2). Similar effects were reported for the Go/Nogo task, with the CPT task indicating issues with response preparation and response inhibition. The flanker task has indicated conflict processing and resource allocation issues. Deficient error detection and/or evaluation were identified by attenuated ERN and Pe components in $\mathrm{AD} / \mathrm{HD}$, with feedback-processing effects also consistently reported. 
The most influential current theories of $\mathrm{AD} / \mathrm{HD}$ propose that symptoms result from a primary deficit in response inhibition (e.g. Barkley, 1997; Quay, 1997), state regulation (Sergeant, 2000), motivational processes (Sonuga-Barke, 2002), or working memory (Rapport et al., 2008). Many of the ERP studies reviewed here do not specifically address or compare these theoretical perspectives, but there are some exceptions. The response inhibition (Barkley, 1997; Quay, 1997) and cognitive energetic models (Sergeant, 2000; Sergeant, 2005) have lent themselves readily to consideration using ERP tasks/methodology. Studies examining the effect of energetic factors on inhibitory processing report at least partial support for the Cognitive Energetic Model (Wiersema et al., 2005b; Wiersema et al., 2006; Benikos and Johnstone, 2009; Johnstone et al., 2010b; Johnstone and Galletta, in press). Several studies not directly examining energetic factors also present ERP data interpreted as supporting the role of suboptimal energetic state regulation in AD/HD (Banaschewski et al., 2003; Banaschewski et al., 2004; van Mourik et al., 2007; Kratz et al., 2011), in children with AD/HDcom but not AD/HDin (Johnstone et al., 2003), and also in younger children displaying AD/HD characteristics (Spronk et al., 2008). Liotti et al. (2009) presented a similar conclusion, with their results indicating deficient cognitive monitoring operations, rather than a simple account in terms of inhibitory control. Groom et al. (2010b) identified the important role of motivational factors, providing some support for the model proposed by Sonuga-Barke (2002). There is also ERP evidence for a developmental lag in inhibition but not attention processes (Doehnert et al., 2010), in line with EEG findings which characterise AD/HD in terms of a maturational lag (see Barry et al., 2003a).

While it is acknowledged that $\mathrm{AD} / \mathrm{HD}$ is an aetiologically and biologically heterogeneous disorder, many studies have failed to tightly control the composition of their clinical group and/or the age-range of their participants, with some other studies having very small sample sizes. Also, there is a lack of emphasis on replication and extension studies using exacting participant, task, and analysis parameters. Of course replication is difficult in light of the many variables reported to moderate $\mathrm{AD} / \mathrm{HD}-\mathrm{ERP}$ relationships, such as characteristics of the task (e.g. stimulus presentation modality, difficulty, stimulus quality, time-on-task, event-rate) and the participants (e.g. age, gender, medication status/type, co-morbidities, personal/familial history of psychiatric and substance use disorders). These factors contribute to a lack of consistency in behavioural and ERP outcomes, and delay the emergence of a clear understanding of robust ERP effects characterising children and adolescents with $\mathrm{AD} / \mathrm{HD}$. This can be understood in terms of the many challenges of conducting research involving children and clinical groups, but a more rigorous approach is needed to increase the consistency and specificity of results. As an aside, it should be noted that gender effects have received little attention in the AD/HD-ERP literature to date. Some studies include a small proportion of female participants, while others include only males (the gender that is diagnosed most frequently), while 50/50 splits on gender and groups consisting entirely of female are rare.

In addition to the group composition and age-range factors mentioned above, this area of research would benefit from more careful consideration of (1) the influence of co-morbid disorders 
using an optimal four-group design, (2) the links between ERP effects and "state" factors as reflected in the EEG, (3) the relationship between differences found in early vs. later ERP components (requiring a standard approach to quantification and analysis of a broad range of components wherever possible), and (4) the use of EEG/ERPs in diagnosis. These were identified in our previous review (Barry et al., 2003b), but have yet to receive the attention they deserve. We also urge researchers to target theory-based predictions when designing their studies. It is time to move beyond describing the ERP deficits associated with this syndrome - rather, we should use ERPs to probe and understand the underlying brain dysfunctions producing the symptom profile of $\mathrm{AD} / \mathrm{HD}$. 


\section{$\underline{\text { References }}$}

Albrecht B, Banaschewski T, Brandeis D, Heinrich H, Rothenberger A. Response inhibition deficits in externalizing child psychiatric disorders: An ERP-study with the Stop-task. Behav Brain Funct 2005;9:1-22.

Albrecht B, Brandeis D, Uebel H, Heinrich H, Müller UC, Hasselhorn M, et al. Action monitoring in boys with ADHD, their nonaffected siblings and normal controls: Evidence for conflict monitoring as an endophenotype for ADHD. Biol Psychiatry 2008;64:615-25.

Alexander DM, Hermens DF, Keage HA, Clark C, Williams LM, Kohn MR, et al. Event-related wave activity in the EEG provides new marker of ADHD. Clin Neurophysiol 2008;119:163-79.

Association AP. Diagnostic and Statistical Manual of Mental Disorders (Revised 4th Ed.). Washington, DC: American Psychiatric Association; 2000.

Banaschewski T, Brandeis D, Heinrich H, Albrecht B, Brunner E, Rothenberger A. Association of ADHD and conduct disorder--brain electrical evidence for the existence of a distinct subtype. J Child Psychol Psychiatry 2003;44:356-76.

Banaschewski T, Brandeis D, Heinrich H, Albrecht B, Brunner E, Rothenberger A. Questioning inhibitory control as the specific deficit of ADHD - evidence from brain electrical activity. J Neural Transm 2004;111:841-64.

Banaschewski T, Yordanova J, Kolev V, Heinrich H, Albrecht B, Rothenberger A. Stimulus context and motor preparation in attention-deficit/hyperactivity disorder. Biol Psychol 2008;77:53-62.

Barkley RA. Behavioral inhibition, sustained attention, and executive functions: Constructing a unifying theory of ADHD. Psychol Bull 1997;121:65-94.

Barry RJ, Clarke AR, Johnstone SJ. A review of electrophysiology in attention-deficit/hyperactivity disorder: I. Qualitative and quantitative electroencephalography. Clin Neurophysiol 2003a;114:17183.

Barry RJ, Clarke AR, McCarthy R, Selikowitz M, Brown CR. Event-related potentials in two DSMIV subtypes of Attention-Deficit/Hyperactivity Disorder: An investigation using a combined modality auditory/visual oddball task. In: Oades RD, editor. Attention-deficit/hyperactivity disorder (AD/HD) and the hyperkinetic syndrome (HKS): Current ideas and ways forward. NY: Nova Publishers, Inc, 2006: 229-47.

Barry RJ, Clarke AR, McCarthy R, Selikowitz M, Brown CR. Event-related potentials in children with Attention-Deficit/Hyperactivity Disorder and excess beta activity in the EEG. Acta Neuropsychol 2009;7:249-63.

Barry RJ, Johnstone SJ, Clarke AR. A review of electrophysiology in attention-deficit/hyperactivity disorder: II. Event-related potentials. Clin Neurophysiol 2003b;114:184-98.

Basar-Eroglu C, Basar E, Demiralp T, Schuermann M. P300-response: possible psychophysiological correlates in delta and theta frequency channels: a review. Int J Psychophysiol 1992;13:161-79.

Belopolsky AV, Peterson MS, Kramer AF. Visual search in temporally segregated displays: Converging operations in the study of the preview benefit. Cog Brain Res 2005;24:453-66.

Benikos N, Johnstone SJ. Arousal-state modulation in children with AD/HD. Clin Neurophysiol 2009;120:30-40. 
Brandeis D, Banaschewski T, Baving L, Georgiewa P, Blanz B, Warnke A, et al. Multicenter P300 brain mapping of impaired attention to cues in hyperkinetic children. J Am Acad Child Adolesc Psychiatry 2002;41:990-8.

Brown CR, Clarke AR, Barry RJ, McCarthy R, Selikowitz M, Magee C. Event related potentials in Attention-Deficit/Hyperactivity Disorder of the predominantly inattentive type: An investigation of EEG-defined subtypes. Int J Psychophysiol 2005;58:94-107.

Broyd SJ, Johnstone SJ, Barry RJ, Clarke AR, McCarthy R, Selikowitz M, et al. The effect of methylphenidate on response inhibition and the event-related potential of children with Attention Deficit/Hyperactivity Disorder. Int J Psychophysiol 2005;58:47-58.

Burgio-Murphy A, Klorman R, Shaywitz SE, Fletcher JM, Marchione KE, Holahan J, et al. Errorrelated event-related potentials in children with attention-deficit hyperactivity disorder, oppositional defiant disorder, reading disorder, and math disorder. Biol Psychol 2007;75:75-86.

Dimoska A, Johnstone SJ, Barry RJ, Clarke AR. Inhibitory motor control in children with attentiondeficit/hyperactivity disorder: Event-related potentials in the stop-signal paradigm. Biol Psychiatry 2003;54:1345-54.

Doehnert M, Brandeis D, Imhof K, Drechsler R, Steinhausen H-C. Mapping attentiondeficit/hyperactivity disorder from childhood to adolescence - No neurophysiologic evidence for a developmental lag of attention but some for inhibition. Biol Psychiatry 2010;67:608-16.

Doehnert M, Brandeis D, Straub M, Steinhausen H-C, Drechsler R. Slow cortical potential neurofeedback in attention deficit hyperactivity disorder: is there neurophysiological evidence for specific effects? J Neural Transm 2008;115:1445-56.

Du J, Li J, Wang Y, Jiang Q, Livesley W, Jang KL, et al. Event-related potentials in adolescents with combined ADHD and CD disorder: A single stimulus paradigm. Brain Cogn 2006;60:70-5.

Geurts HM, Verte S, Oosterlaan J, Roeyers H, Sergeant JA. ADHD subtypes: Do they differ in their executive functioning profile? Arch Clin Neuropsychol 2005;20:457-77.

Gomarus H, Wijers AA, Minderaa RB, Althaus M. ERP correlates of selective attention and working memory capacities in children with ADHD and/or PDD-NOS. Clin Neurophysiol 2009;120:60-72.

Gomez R, Harvey J, Quick C, Scharer I, Harris G. DSM-IV ADHD: confirmatory factor models, prevalence, and gender and age differences based on parent and teacher ratings of Australian primary school children. J Child Psychol Psychiatry 1999;40:265-74.

Groen Y, Wijers AA, Mulder LJ, Waggeveld B, Minderaa RB, Althaus M. Error and feedback processing in children with ADHD and children with autistic spectrum disorder: An EEG eventrelated potential study. Clin Neurophysiol 2008;119:2476-93.

Groom MJ, Bates AT, Jackson GM, Calton TG, Liddle PF, Hollis C. Event-related potentials in adolescents with schizophrenia and their siblings: A comparison with attention-deficit/hyperactivity disorder. Biol Psychiatry 2008;63:784-92.

Groom MJ, Cahill JD, Bates AT, Jackson GM, Calton TG, Liddle PF, et al. Electrophysiological indices of abnormal error-processing in adolescents with attention deficit hyperactivity disorder (ADHD). J Child Psychol Psychiatry 2010a;51:66-76. 
Groom MJ, Scerif G, Liddle PF, Batty MJ, Liddle EB, Roberts KL, et al. Effects of motivation and medication on electrophysiological markers of response inhibition in children with attentiondeficit/hyperactivity disorder. Biol Psychiatry 2010b;67:624-31.

Gumenyuk V, Korzyukov O, Escera C, Hämäläinen M, Huotilainen M, Häyrinen T, et al. Electrophysiological evidence of enhanced distractibility in ADHD children. Neurosci Lett 2005;374:212-7.

Heinrich H, Gevensleben H, Freisleder FJ, Moll GH, Rothenberger A. Training of slow cortical potentials in attention-deficit/hyperactivity disorder: Evidence for positive behavioral and neurophysiological effects. Biol Psychiatry 2004;55:772-5.

Holroyd CB, Baker TE, Kerns KA, Muller U. Electrophysiological evidence of atypical motivation and reward processing in children with attention-deficit hyperactivity disorder. Neuropsychologia 2008;46:2234-42.

Johnstone SJ, Barry RJ, Clarke AR. Behavioural and ERP indices of response inhibition during a Stop-signal task in children with two subtypes of Attention-Deficit Hyperactivity Disorder. Int J Psychophysiol 2007a;66:37-47.

Johnstone SJ, Barry RJ, Dimoska A. Event-related slow-wave activity in two subtypes of attentiondeficit/hyperactivity disorder. Clin Neurophysiol 2003;114:504-14.

Johnstone SJ, Barry RJ, Markovska V, Dimoska A, Clarke AR. Response inhibition and interference control in children with AD/HD: A visual ERP investigation. Int J Psychophysiol 2009;72:145-53.

Johnstone SJ, Dimoska A, Smith JL, Barry RJ, Pleffer CB, Chiswick D, et al. The development of stop-signal and Go/Nogo response inhibition in children aged 7-12 years: Performance and eventrelated potential indices. Int J Psychophysiol 2007b;63:25-38.

Johnstone SJ, Galletta D. Event-rate effects in the flanker task: ERPs and task performance in children with and without $\mathrm{AD} / \mathrm{HD}$. Int J Psychophysiol in press.

Johnstone SJ, Roodenrys S, Phillips E, Watt AJ, Mantz S. Combined working memory and inhibition training for children with AD/HD. ADHD Attention Deficit and Hyperactivity Disorders 2010a;2:3142.

Johnstone SJ, Watt AJ, Dimoska A. Varying required effort during interference control in children with AD/HD: Task performance and ERPs. Int J Psychophysiol 2010b;76:174-85.

Jonkman L, Kenemans J, Kemner C, Verbaten M, van Engeland H. Dipole source localization of event-related brain activity indicative of an early visual selective attention deficit in ADHD children. Clin Neurophysiol 2004;115:1537-49.

Jonkman LM, van Melis JJM, Kemner C, Markus CR. Methylphenidate improves deficient error evaluation in children with ADHD: An event-related brain potential study. Biol Psychol 2007;76:21729.

Keage HD, Clark CR, Hermens DF, Kohn MR, Clarke S, Williams LM, et al. Distractibility in $\mathrm{AD} / \mathrm{HD}$ predominantly inattentive and combined subtypes: the P3a ERP component, heart rate and performance. J Integr Neurosci 2006;5:139-58.

Klorman R, Thatcher JE, Shaywitz SE, Fletcher JM, Marchione KE, Holahan JM, et al. Effects of event probability and sequence on children with attention-deficit/hyperactivity, reading and math disorder. Biol Psychiatry 2002;52:795-804. 
Kratz O, Studer P, Malcherek S, Erbe K, Moll GH, Heinrich H. Attentional processes in children with ADHD: An event-related potential study using the attention network test. Int J Psychophysiol 2011;81:82-90.

Krauel K, Duzel E, Hinrichs H, Lenz D, Herrmann CS, Santel S, et al. Electrophysiological correlates of semantic processing during encoding of neutral and emotional pictures in patients with ADHD. Neuropsychologia 2009;47:1873-82.

Kropotov JD, Grin-Yatsenko VA, Ponomarev VA, Chutko LS, Yakovenko EA, Nikishena IS. ERPs correlates of EEG relative beta training in ADHD children. Int J Psychophysiol 2005;55:23-34.

Lawrence CA, Barry RJ, Clarke AR, Johnstone SJ, McCarthy R, Selikowitz M, et al. Methylphenidate effects in attention deficit/hyperactivity disorder: Electrodermal and ERP measures during a continuous performance task. Psychopharmacology 2005;183:81-91.

Lenz D, Krauel K, Flechtner H, Schadow J, Hinrichs H, Herrmann CS. Altered evoked gamma-band responses reveal impaired early visual processing in ADHD children. Neuropsychologia 2010;48:1985-93.

Lenz D, Krauel K, Schadow J, Baving L, Duzel E, Herrmann CS. Enhanced gamma-band activity in ADHD patients lacks correlation with memory performance found in healthy children. Brain Res 2008;1235:117-32.

Liotti M, Pliszka SR, Higgins K, Perez R, III, Semrud-Clikeman M. Evidence for specificity of ERP abnormalities during response inhibition in ADHD children: A comparison with reading disorder children without ADHD. Brain Cogn 2009;72:228-37.

Liotti M, Pliszka SR, Perez R, Kothmann D, Woldorff MG. Abnormal brain activity related to performance monitoring and error detection in children with ADHD. Cortex 2005;41:377-88.

Liotti M, Pliszka SR, Perez RI, Luus B, Glahn D, Semrud-Clikeman M. Electrophysiological correlates of response inhibition in children and adolescents with ADHD: Influence of gender, age, and previous treatment history. Psychophysiology 2007;44:936-48.

Lopez V, Lopez-Calderon J, Ortega R, Kreither J, Carrasco X, Rothhammer P, et al. Attention-deficit hyperactivity disorder involves differential cortical processing in a visual spatial attention paradigm. Clin Neurophysiol 2006;117:2540-8.

Overtoom CC, Kenemans J, Verbaten MN, Kemmer C, van der Molen MW, van Engeland H, et al. Inhibition in children with attention-deficit/hyperactivity disorder: A psychophysiological study of the stop task. Biol Psychiatry 2002;51:668-76.

Quay HC. Inhibition and attention deficit hyperactivity disorder. J Child Psychol Psychiatry 1997;25:7-13.

Rapport MD, Alderson RM, Kofler MJ, Sarver DE, Bolden J, Sims V. Working memory deficits in boys with attention-deficit/hyperactivity disorder (ADHD): the contribution of central executive and subsystem processes. J Child Psychol Psychiatry 2008;36:825-37.

Sanders AF. Towards a model of stress and human performance. Acta Psychologica 1983;53:61-97.

Senderecka M, Grabowska A, Gerc K, Szewczyk J, Chmylak R. Event-related potentials in children with attention deficit hyperactivity disorder: An investigation using an auditory oddball task. Int $\mathrm{J}$ Psychophysiol 2012a;85:106-15. 
Senderecka M, Grabowska A, Szewczyk J, Gerc K, Chmylak R. Response inhibition of children with ADHD in the stop-signal task: An event-related potential study. Int J Psychophysiol 2012b;85:93-105.

Sergeant J. The cognitive-energetic model: An empirical approach to Attention-Deficit Hyperactivity Disorder. Neurosci Biobehav Rev 2000;24:7-12.

Sergeant JA. Modeling attention-deficit/hyperactivity disorder: A critical appraisal of the cognitiveenergetic model. Biol Psychiatry 2005;57:1248-55.

Shen I, Tsai S-Y, Duann J-R. Inhibition control and error processing in children with attention deficit/hyperactivity disorder: An event-related potentials study. Int J Psychophysiol 2011;81:1-11.

Shiels K, Hawk LW, Jr. Self-regulation in ADHD: The role of error processing. Clin Psychol Rev 2010;30:951-61.

Smith JL, Johnstone SJ, Barry RJ. Aiding diagnosis of attention-deficit/hyperactivity disorder and its subtypes: Discriminant function analysis of event-related potential data. J Child Psychol Psychiatry 2003;44:1067-75.

Smith JL, Johnstone SJ, Barry RJ. Inhibitory processing during the Go/NoGo task: An ERP analysis of children with attention-deficit/hyperactivity disorder. Clin Neurophysiol 2004;115:1320-31.

Sonuga-Barke EJ. Psychological heterogeneity in ADHD - a dual pathway model of behaviour and cognition. Behav Brain Res 2002;130:29-36.

Spronk M, Jonkman L, Kemner C. Response inhibition and attention processing in 5- to 7-year-old children with and without symptoms of ADHD: An ERP study. Clin Neurophysiol 2008;119:2738-52.

Valko L, Doehnert M, Muller UC, Schneider G, Albrecht B, Drechsler R, et al. Differences in neurophysiological markers of inhibitory and temporal processing deficits in children and adults with ADHD. J Psychophysiol 2009;23:235-46.

Van De Voorde S, Roeyers H, Wiersema JR. Error monitoring in children with adhd or reading disorder: An event-related potential study. Biol Psychol 2010;84:176-85.

van der Stelt O, van der Molen MW, Gunning W, Kok A. Neuroelectrical signs of selective attention to color in boys with attention-deficit hyperactivity disorder. Cogn Brain Res 2001;12:245-64.

van Meel CS, Heslenfeld DJ, Oosterlaan J, Luman M, Sergeant JA. ERPS associated with monitoring and evaluation of monetary reward and punishment in children with ADHD. J Child Psychol Psychiatry 2011;52:942-53.

van Meel CS, Heslenfeld DJ, Oosterlaan J, Sergeant JA. Adaptive control deficits in attentiondeficit/hyperactivity disorder (ADHD): The role of error processing. Psychiatry Res 2007;151:211-20.

van Meel CS, Oosterlaan J, Heslenfeld DJ, Sergeant JA. Telling good from bad news: ADHD differentially affects processing of positive and negative feedback during guessing. Neuropsychologia 2005;43:1946-54.

van Mourik R, Oosterlaan J, Heslenfeld DJ, Konig CE, Sergeant JA. When distraction is not distracting: A behavioral and ERP study on distraction in ADHD. Clin Neurophysiol 2007;118:185565.

van Mourik R, Sergeant JA, Heslenfeld D, Konig C, Oosterlaan J. Auditory conflict processing in ADHD. J Child Psychol Psychiatry 2010;52:265-74. 
Wangler S, Gevensleben H, Albrecht B, Studer P, Rothenberger A, Moll GH, et al. Neurofeedback in children with ADHD: Specific event-related potential findings of a randomized controlled trial. Clin Neurophysiol 2010;122:942-50.

Wiersema JR, Roeyers H. ERP correlates of effortful control in children with varying levels of ADHD symptoms. J Child Psychol Psychiatry 2009;37:327-36.

Wiersema JR, van der Meere JJ, Roeyers H. ERP correlates of impaired error monitoring in children with ADHD. J Neural Transm 2005a;112:1417-30.

Wiersema JR, van der Meere JJ, Roeyers H. State regulation and response inhibition in children with ADHD and children with early- and continuously treated phenylketonuria: An event-related potential comparison. J Inherit Metab Dis 2005b;28:831-43.

Wiersema R, van der Meere J, Roeyers H, Van Coster R, Baeyens D. Event rate and event-related potentials in ADHD. J Child Psychol Psychiatry 2006;47:560-7.

Wild-Wall N, Oades RD, Schmidt-Wessels M, Christiansen H, Falkenstein M. Neural activity associated with executive functions in adolescents with attention-deficit/hyperactivity disorder (ADHD). Int J Psychophysiol 2009;74:19-27.

Williams LM, Hermens DF, Palmer D, Kohn M, Clarke S, Keage H, et al. Misinterpreting emotional expressions in attention-deficit/hyperactivity disorder: Evidence for a neural marker and stimulant effects. Biol Psychiatry 2008;63:917-26.

Wolraich ML, Hannah JN, Pinnock TY, Baumgaertel A, Brown J. Comparison of diagnostic criteria for attention-deficit hyperactivity disorder in a county-wide sample. J Am Acad Child Adolesc Psychiatry 1996;35:319-24.

Yorbik O, Ozdag M, Olgun A, Senol M, Bek S, Akman S. Potential effects of zinc on information processing in boys with attention deficit hyperactivity disorder. Prog Neuropsychopharmacol Biol Psychiatry 2008;32:662-7.

Yordanova J, Heinrich H, Kolev V, Rothenberger A. Increased event-related theta activity as a psychophysiological marker of comorbidity in children with tics and attention-deficit/hyperactivity disorders. Neuroimage 2006;32:940-55.

Zhang JS, Wang Y, Cai RG, Yan CH. The brain regulation mechanism of error monitoring in impulsive children with ADHD-An analysis of error related potentials. Neurosci Lett 2009;460:11-5. 
Table 1. Studies in the area of attention. Papers in this table are grouped according to task type and then year of publication. Greyed cells in the Age range column indicate optimal consideration of age.

\begin{tabular}{|c|c|c|c|c|c|c|c|c|c|c|c|}
\hline Study & AD/HD type & $\mathbf{N}$ & Other groups & $\mathbf{N}$ & Diagnosis & $\begin{array}{l}\text { Age } \\
\text { range }\end{array}$ & Task type & Modality & $\begin{array}{l}\text { Stimulus } \\
\text { proportion }\end{array}$ & $\begin{array}{l}\text { Filter } \\
\text { range } \\
\text { (Hz) }\end{array}$ & ERP components \\
\hline $\begin{array}{l}\text { van der Stelt et } \\
\text { al. } 2001\end{array}$ & Com & 24 & Control & 24 & DSM-IV & $7-12$ & $\begin{array}{l}\text { Selective } \\
\text { attention }\end{array}$ & Visual & $25 \%$ target & $0.16-40$ & $\begin{array}{l}\text { FSP, SN, N2b, P3b, } \\
\text { LN }\end{array}$ \\
\hline $\begin{array}{l}\text { Jonkman et al. } \\
2004\end{array}$ & ADHD & 18 & Control & 18 & $\begin{array}{l}\text { DSM-III- } \\
\mathrm{R}\end{array}$ & $7-13$ & Dual oddball & Visual & $20 \%$ target & $0.01-30$ & FSP, SN, N2b \\
\hline $\begin{array}{l}\text { Brandeis et al. } \\
2002\end{array}$ & $\mathrm{HD}^{1}$ & 57 & Control & 57 & ICD-10 & 8-14 & $\mathrm{CPT}$ & Visual & $10 \%$ Go, Nogo & $0.1-30$ & P3a, Р3b \\
\hline $\begin{array}{l}\text { Banaschewski et } \\
\text { al. } 2003\end{array}$ & Com & 15 & $\begin{array}{l}\mathrm{HCD}^{2}(16), \\
\text { ODD/CD (15), } \\
\text { Control (18) }\end{array}$ & 49 & ICD-10 & $8-14$ & CPT & Visual & $10 \%$ Go, Nogo & $0.1-30$ & $\begin{array}{l}\text { P1/N1, P2/N2, P3b, } \\
\text { CNV }\end{array}$ \\
\hline $\begin{array}{l}\text { Lawrence et al. } \\
2005\end{array}$ & Com & 18 & Control & 18 & DSM-IV & 8-13.4 & $\mathrm{CPT}$ & Visual & $8 \%$ Go & $0.5-30$ & $\mathrm{~N} 1, \mathrm{P} 2, \mathrm{~N} 2, \mathrm{P} 3$ \\
\hline $\begin{array}{l}\text { Spronk et al. } \\
2008^{3}\end{array}$ & $\begin{array}{l}\text { ADHD } \\
\text { characteristics }\end{array}$ & 12 & Control & 15 & None & $5-7$ & CPT & Visual & $10 \%$ Go, Nogo & $0.5-50$ & $\begin{array}{l}\text { Cue P2 \& P3, CNV, } \\
\text { Nogo N2 \& P3, Go } \\
\text { P3 }\end{array}$ \\
\hline $\begin{array}{l}\text { Klorman et al. } \\
2002\end{array}$ & $\begin{array}{l}\text { Com (86), In } \\
(38)^{4}\end{array}$ & 124 & $\begin{array}{l}\text { Control (28), } \\
\text { Comorbid }^{5}(54)\end{array}$ & 82 & DSM-IV & $7-13.5$ & Oddball & Visual & $\begin{array}{l}\text { Cond 1: } 17 \% \\
\text { target, Cond 2: } \\
50 \% \text { target }\end{array}$ & $0.01-100$ & N2, P3b \\
\hline $\begin{array}{l}\text { Brown et al. } \\
2005\end{array}$ & In & 54 & Control & 27 & DSM-IV & $8-12$ & $\begin{array}{l}\text { Multi-modal } \\
\text { oddball }\end{array}$ & $\begin{array}{l}\text { Auditory and } \\
\text { visual }\end{array}$ & $\begin{array}{l}\text { 20\% auditory } \\
\text { target }\end{array}$ & $0.5-70$ & $\begin{array}{l}\text { Auditory N1, P2, N2, } \\
\text { P3. Visual P1, N1, } \\
\text { P2, N2, P3 }\end{array}$ \\
\hline Barry et al. 2006 & $\begin{array}{l}\text { Com (25), In } \\
\text { (25) }\end{array}$ & 50 & Control & 25 & DSM-IV & $8-12$ & $\begin{array}{l}\text { Multi-modal } \\
\text { oddball }\end{array}$ & $\begin{array}{l}\text { Auditory and } \\
\text { visual }\end{array}$ & $\begin{array}{l}20 \% \text { auditory } \\
\text { target }\end{array}$ & $0.5-70$ & $\begin{array}{l}\text { Auditory N1, P2, N2, } \\
\text { P3. Visual P1, N1, } \\
\text { P2, N2, P3 }\end{array}$ \\
\hline Du et al. 2006 & $\mathrm{ADHD}+\mathrm{CD}$ & 20 & Control & 20 & DSM-IV & $13-17$ & $\begin{array}{l}\text { One stimulus } \\
\text { oddball }\end{array}$ & Auditory & $20 \%$ target & $0.01-50$ & N1, P2, N2, P3 \\
\hline $\begin{array}{l}\text { Lopez et al. } \\
2007\end{array}$ & Com & 10 & Control & 10 & DSM-IV & $9-14$ & Spatial oddball & Visual & $10 \%$ target & $0.5-30$ & P1, N1, P3 \\
\hline $\begin{array}{l}\text { Yorbik et al. } \\
2008\end{array}$ & Com & 28 & Control & 24 & DSM-IV & $7-12$ & Oddball & Auditory & $20 \%$ target & $0.5-50$ & P1, N2, P3 \\
\hline Barry et al. 2009 & Com & 40 & Control & 20 & DSM-IV & $8-12$ & $\begin{array}{l}\text { Multi-modal } \\
\text { oddball }\end{array}$ & $\begin{array}{l}\text { Auditory and } \\
\text { visual }\end{array}$ & $\begin{array}{l}20 \% \text { auditory } \\
\text { target }\end{array}$ & $0.5-70$ & $\begin{array}{l}\text { Auditory N1, P2, N2, } \\
\text { P3. Visual P1, N1, } \\
\text { P2, N2, P3 }\end{array}$ \\
\hline $\begin{array}{l}\text { Senderecka et } \\
\text { al. } 2012\end{array}$ & Com & 20 & Control & 20 & DSM-IV & $6.9-12.3$ & Oddball & Auditory & 34\% target & $0.5-70$ & P2, N2, P3 \\
\hline $\begin{array}{l}\text { Gumenyuk et al. } \\
2005\end{array}$ & $\mathrm{AD} / \mathrm{HD}^{2}$ & 10 & Control & 10 & DSM-IV & $8-10$ & Distraction & $\begin{array}{l}\text { Visual with } \\
\text { auditory } \\
\text { distracters }\end{array}$ & $20 \%$ Novel & $1.0-30$ & P3a, LN \\
\hline
\end{tabular}




\begin{tabular}{|c|c|c|c|c|c|c|c|c|c|c|c|}
\hline $\begin{array}{l}\text { van Mourik et } \\
\text { al. } 2007\end{array}$ & $\begin{array}{l}\text { Com (22), In } \\
\text { (3) }\end{array}$ & 25 & Control & 18 & DSM-IV & 8-12 & Distraction & $\begin{array}{l}\text { Visual with } \\
\text { auditory } \\
\text { distracters }\end{array}$ & $20 \%$ distracter & $0.25-30$ & $\begin{array}{l}\text { Early P3a, Late P3a, } \\
\text { LN }\end{array}$ \\
\hline $\begin{array}{l}\text { Keage et al. } \\
2006\end{array}$ & $\begin{array}{l}\text { Com (72), In } \\
(57)^{5}\end{array}$ & 127 & Control & 129 & DSM-IV & $\begin{array}{l}\text { 7-17 (2 } \\
\text { groups) }\end{array}$ & $\begin{array}{l}\text { Working } \\
\text { memory plus } \\
\text { distracters }\end{array}$ & Visual & $16 \%$ distracter & $0.01-25$ & P3a \\
\hline
\end{tabular}

Com AD/HD Combined subtype. HD Hyperkinetic disorder. In AD/HD Inattentive subtype. CPT Continuous performance task. CNV Contingent negative variation. FSP Frontal selection positivity. SN Selection negativity. LN Late negativity. ${ }^{1}$ Hyperkinetic Disorder - Large proportion had Hyperkinetic Conduct Disorder. ${ }^{2}$ Hyperkinetic Conduct Disorder. ${ }^{3}$ Also considered in Inhibitory Control section. ${ }^{4}$ Subtypes considered as separate groups. ${ }^{5}$ Combinations of co-morbid Reading Disorder and Maths Disorder with Not-ADHD, Combined and Inattentive ADHD, with twelve unique groups in total. ${ }^{6}$ Subtype not clearly specified. 
Table 2. Studies in the area of inhibitory control. Papers in this table are grouped according to task type and then year of publication. Greyed cells in the Age range column indicate optimal consideration of age.

\begin{tabular}{|c|c|c|c|c|c|c|c|c|c|c|c|}
\hline Study & $\begin{array}{l}\text { AD/HD } \\
\text { type }\end{array}$ & $\mathbf{N}$ & Other groups & $\mathbf{N}$ & DSM & Age range & Task type & Modality & $\begin{array}{l}\begin{array}{l}\text { Stimulus } \\
\text { proportion }\end{array} \\
\end{array}$ & $\begin{array}{l}\text { Filter } \\
\text { range } \\
(\mathrm{Hz})\end{array}$ & ERP components \\
\hline $\begin{array}{l}\text { Overtoom et al. } \\
2002\end{array}$ & ADHD & 16 & Control & 16 & III-R & $7-12$ & Stop Signal & $\begin{array}{l}\text { Visual } \\
\text { primary, } \\
\text { Auditory } \\
\text { stop }\end{array}$ & $40 \%$ Stop & $0-40$ & $\begin{array}{l}\text { Mean amplitude 100- } \\
400 \mathrm{~ms} \text { in } 50 \mathrm{~ms} \\
\text { segments }\end{array}$ \\
\hline $\begin{array}{l}\text { Dimoska et al. } \\
2003\end{array}$ & $\begin{array}{l}\text { Com (11), } \\
\text { In (2) }\end{array}$ & 13 & Control & 13 & DSM-IV & 7.5-12 & Stop Signal & $\begin{array}{l}\text { Visual } \\
\text { primary, } \\
\text { Auditory } \\
\text { stop }\end{array}$ & 30\% Stop & $0.1-30$ & N1, P2, N2, P3 \\
\hline $\begin{array}{l}\text { Albrecht et al. } \\
2005\end{array}$ & Com & 10 & $\begin{array}{l}\text { Control (11), } \\
\text { ODD/CD }{ }^{1}(8), \\
\text { ADHD/ODD/CD }{ }^{2}(11)\end{array}$ & 30 & ICD-10 & 8-14 & Stop Signal & $\begin{array}{l}\text { Visual } \\
\text { primary, } \\
\text { Visual stop }\end{array}$ & $50 \%$ Stop & $0.1-30$ & Stop N2, microstates \\
\hline $\begin{array}{l}\text { Johnstone et al. } \\
\text { 2007a }\end{array}$ & $\begin{array}{l}\text { Com (13), } \\
\text { In }\left(12^{13}\right.\end{array}$ & 25 & Control & 13 & DSM-IV & $8-14$ & Stop Signal & $\begin{array}{l}\text { Visual } \\
\text { primary, } \\
\text { Auditory } \\
\text { stop }\end{array}$ & $30 \%$ Stop & $0.1-30$ & N1, P2, N2, P3 \\
\hline $\begin{array}{l}\text { Liotti et al. } \\
2007\end{array}$ & Com & 36 & Control & 30 & DSM-IV & $9-15$ & Stop Signal & $\begin{array}{l}\text { Visual } \\
\text { primary, } \\
\text { Visual stop }\end{array}$ & 25\% Stop & $\begin{array}{l}0.01- \\
100 \\
\end{array}$ & N2, Nogo P3, LP \\
\hline $\begin{array}{l}\text { Liotti et al. } \\
2009\end{array}$ & Com & 16 & $\begin{array}{l}\text { Control (22), reading } \\
\text { disorder (14) }\end{array}$ & 36 & DISC-IV & $9-15$ & Stop Signal & $\begin{array}{l}\text { Visual } \\
\text { primary, } \\
\text { Visual stop }\end{array}$ & $25 \%$ Stop & $\begin{array}{l}0.01- \\
100\end{array}$ & Nogo P3, N2 \\
\hline $\begin{array}{l}\text { Shen et al. } \\
2011^{4}\end{array}$ & $\begin{array}{l}\text { Com (8), } \\
\text { Hyp (2), In } \\
\text { (4) }\end{array}$ & 14 & Control & 14 & DSM-IV & $6-10$ & Stop Signal & $\begin{array}{l}\text { Visual } \\
\text { primary, } \\
\text { Visual stop }\end{array}$ & $25 \%$ Stop & $0.01-40$ & $\begin{array}{l}\text { P1, N1, N2, LP, } \\
\text { ERN, Pe }\end{array}$ \\
\hline $\begin{array}{l}\text { Senderecka et } \\
\text { al. 2012b }\end{array}$ & Com & 20 & Control & 20 & DSM-IV & $6.9-12.3$ & Stop Signal & $\begin{array}{l}\text { Visual } \\
\text { primary, } \\
\text { Auditory } \\
\text { stop }\end{array}$ & $25 \%$ Stop & $0.5-70$ & P2, N2, P3, ERN, Pe \\
\hline $\begin{array}{l}\text { Smith et al. } \\
2004\end{array}$ & Com & 12 & Control & 12 & DSM-IV & $7-12$ & $\begin{array}{l}\text { Cued Go- } \\
\text { Nogo }\end{array}$ & Auditory & Nogo 30\% & $0.1-45$ & $\begin{array}{l}\text { Warning } \\
\text { P1/N1/P2/N2, Go- } \\
\text { Nogo } \\
\text { P1/N1/P2/N2/P3 }\end{array}$ \\
\hline $\begin{array}{l}\text { Broyd et al. } \\
2005\end{array}$ & Com & 18 & Control & 18 & DSM-IV & 8-14 (2 groups) & $\begin{array}{l}\text { Cued Go- } \\
\text { Nogo }\end{array}$ & Auditory & $30 \%$ Nogo & $0.5-30$ & N1, P2, N2, P3 \\
\hline $\begin{array}{l}\text { Johnstone et al. } \\
2009\end{array}$ & Com & 20 & Control & 20 & DSM-IV & $8-14$ & $\begin{array}{l}\text { Go-Nogo; } \\
\text { Flanker }\end{array}$ & $\begin{array}{l}\text { Visual; } \\
\text { Visual }\end{array}$ & $\begin{array}{l}30 \% \text { Nogo; } \\
30 \%\end{array}$ & $0.1-30$ & $\begin{array}{l}\text { Go-Nogo } \\
\text { N1/P2/N2/P3, }\end{array}$ \\
\hline
\end{tabular}




\begin{tabular}{|c|c|c|c|c|c|c|c|c|c|c|c|}
\hline & & & & & & & & & incongruent & & Flanker N1/P2/N2/P3 \\
\hline $\begin{array}{l}\text { Wiersema and } \\
\text { Roeyers } 2009\end{array}$ & $\begin{array}{l}\text { Com (8), } \\
\text { Hyp (2) }\end{array}$ & 10 & Control & 16 & DSM-IV & $8-13$ & Go-Nogo & Visual & Nogo $20 \%$ & $0.1-30$ & Nogo N2 and P3 \\
\hline $\begin{array}{l}\text { Groom et al. } \\
2008\end{array}$ & Com & 27 & $\begin{array}{l}\text { Control (36), Sch. } \\
\text { (30), Sch. siblings (36) }\end{array}$ & 102 & DSM-IV & $14-21$ & $\begin{array}{l}\text { Oddball; Go } \\
\text { Nogo }\end{array}$ & $\begin{array}{l}\text { Auditory; } \\
\text { Visual }\end{array}$ & $\begin{array}{l}\text { 15\% target; } \\
20 \% \text { Nogo }\end{array}$ & $0.4-12$ & $\begin{array}{l}\text { Oddball P3; Go- } \\
\text { Nogo N2 and P3 }\end{array}$ \\
\hline $\begin{array}{l}\text { Groom et al. } \\
\text { 2010b }\end{array}$ & $\mathrm{Com}^{5}$ & 28 & Control & 28 & DSM-IV & $9-15$ & $\begin{array}{l}\text { Go-Nogo (3 } \\
\text { motivation } \\
\text { conditions) }\end{array}$ & Visual & $25 \%$ Nogo & $0.5-30$ & N2, P3 \\
\hline $\begin{array}{l}\text { Banaschewski } \\
\text { et al. } 2004\end{array}$ & Com & 15 & $\begin{array}{l}\operatorname{HCD}^{6}(16), \text { ODD (15), } \\
\text { Control (18) }\end{array}$ & 49 & ICD-10 & $8-14$ & $\mathrm{CPT}$ & Visual & $10 \%$ Go, Nogo & $0.1-30$ & $\begin{array}{l}\text { P1/N1, P2, N2, P3a, } \\
\text { P3b, LN }\end{array}$ \\
\hline $\begin{array}{l}\text { Valko et al. } \\
2009\end{array}$ & $\begin{array}{l}\text { Com } \\
\text { children } \\
\text { (32), ADHD } \\
\text { adults (22) }\end{array}$ & 54 & $\begin{array}{l}\text { Control children (31), } \\
\text { Control adults (22) }\end{array}$ & 53 & $\begin{array}{l}\text { Children } \\
\text { DSM-IV, } \\
\text { Adults } \\
\text { ADHD-SR }^{7}\end{array}$ & $\begin{array}{l}\text { Children 8-16, } \\
\text { adult mean } 44.7 \\
\text { yrs }\end{array}$ & CPT & Visual & $10 \%$ Go, Nogo & $0.1-30$ & Cue CNV, Nogo P3 \\
\hline $\begin{array}{l}\text { Doehnart et al. } \\
2010\end{array}$ & ADHD & 28 & Control & 25 & III-R & Longitudinal & $\mathrm{CPT}$ & Visual & $10 \%$ Go, Nogo & $0.1-70$ & $\begin{array}{l}\text { Cue P3, Nogo P3, } \\
\text { CNV }\end{array}$ \\
\hline $\begin{array}{l}\text { Jonkman et al. } \\
2007^{4}\end{array}$ & ADHD & 10 & Control & 10 & DSM-III-R & $8-12$ & Flanker & Visual & $\begin{array}{l}25 \% \\
\text { congruent, } \\
\text { incongruent }\end{array}$ & $0.1-30$ & N2, ERN, Pe \\
\hline $\begin{array}{l}\text { Albrecht et al. } \\
2008^{4}\end{array}$ & Com & 68 & $\begin{array}{l}\text { Control (22), Siblings } \\
\text { of ADHD (18) }\end{array}$ & 40 & DSM-IV & $8-15$ & Flanker & Visual & $\begin{array}{l}50 \% \\
\text { congruent, } \\
\text { incongruent }\end{array}$ & $0.1-15$ & N2, Ne and Pe \\
\hline $\begin{array}{l}\text { Wild-Wall et al. } \\
2009^{4}\end{array}$ & Com & 15 & $\begin{array}{l}\text { Control (12), Siblings } \\
\text { of ADHD (12) }\end{array}$ & 24 & DSM-IV & $11-18$ & $\begin{array}{l}\text { Flanker-Nogo } \\
\text { hybrid }\end{array}$ & Visual & $\begin{array}{l}20 \% \\
\text { Incongruent, } \\
\text { Nogo }\end{array}$ & $0.1-30$ & $\begin{array}{l}\text { N2, P3a, Ne/Nc and } \\
\text { Pe/Pc }\end{array}$ \\
\hline $\begin{array}{l}\text { Kratz et al. } \\
2011\end{array}$ & $\begin{array}{l}\operatorname{Com}(15) \text {, } \\
\operatorname{In}(10)^{3}\end{array}$ & 25 & Control & 19 & DSM-IV & $8-11$ & Cued flanker & Visual & $\begin{array}{l}50 \% \\
\text { Congruent, } \\
\text { incongruent }\end{array}$ & $0.05-30$ & $\begin{array}{l}\text { Target P3, Cue P3, } \\
\text { CNV }\end{array}$ \\
\hline $\begin{array}{l}\text { van Mourik et } \\
\text { al. } 2010\end{array}$ & $\begin{array}{l}\text { Com (20), } \\
\text { Hyp (1), In } \\
(3)\end{array}$ & 24 & Control & 24 & DSM-IV & $8-12$ & Stroop & Auditory & $\begin{array}{l}50 \% \\
\text { Congruent, } \\
\text { incongruent }\end{array}$ & $0.1-30$ & $\begin{array}{l}\text { Time windows, not } \\
\text { peaks }\end{array}$ \\
\hline
\end{tabular}

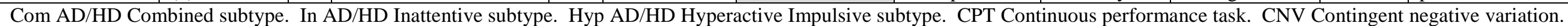

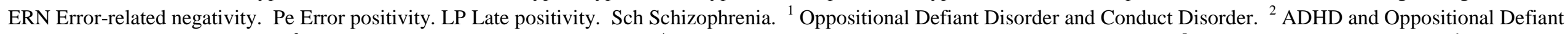

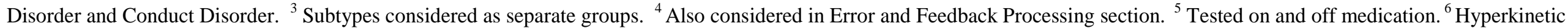

conduct disorder. ${ }^{7}$ Attention Deficit Hyperactivity Disorder Self Report Scale. 
Table 3. Studies in the area of performance monitoring. Error processing papers are presented first, sorted according to task and year. Feedback processing papers follow, sorted according to year of publication. Greyed cells in the Age range column indicate optimal consideration of age.

\begin{tabular}{|c|c|c|c|c|c|c|c|c|c|c|c|}
\hline Study & AD/HD type & $\mathbf{N}$ & Other groups & $\mathbf{N}$ & DSM & $\begin{array}{l}\text { Age } \\
\text { range }\end{array}$ & Task type & Modality & $\begin{array}{l}\text { Stimulus } \\
\text { proportion }\end{array}$ & $\begin{array}{l}\text { Filter } \\
\text { range } \\
(\mathrm{Hz})\end{array}$ & ERP components \\
\hline $\begin{array}{l}\text { Liotti et al. } \\
2005^{1}\end{array}$ & Com & 10 & Control & 10 & $\begin{array}{l}\text { DSM- } \\
\text { IV }\end{array}$ & $9-11$ & Stop Signal & $\begin{array}{l}\text { Visual } \\
\text { primary, } \\
\text { Visual stop }\end{array}$ & $25 \%$ Stop & $0.1-100$ & P3a, ERN \\
\hline $\begin{array}{l}\text { Wiersema et } \\
\text { al. 2005a }\end{array}$ & $\mathrm{Com}^{2}$ & 22 & Control & 15 & $\begin{array}{l}\text { DISC- } \\
\text { IV }\end{array}$ & 7-13 & $\begin{array}{l}\text { Go-Nogo; S1- } \\
\text { S2 }\end{array}$ & $\begin{array}{l}\text { Visual; } \\
\text { Visual }\end{array}$ & $\begin{array}{l}25 \% \text { Nogo; } 50 \% 2 \\
\text { choice }\end{array}$ & $0.01-30$ & ERN, Pe; ERN, Pe \\
\hline $\begin{array}{l}\text { Zhang et al. } \\
2009\end{array}$ & Нyр & 16 & $\begin{array}{l}\text { Control children (16), } \\
\text { adult controls (15) }\end{array}$ & 31 & $\begin{array}{l}\text { DSM- } \\
\text { IV }\end{array}$ & $7-11$ & Go-Nogo & Visual & $25 \%$ Nogo & $0.1-30$ & ERN, Pe \\
\hline $\begin{array}{l}\text { Groom et al. } \\
\text { 2010a }\end{array}$ & Com & 23 & Control & 19 & $\begin{array}{l}\text { DSM- } \\
\text { IV }\end{array}$ & $14-17$ & Go-Nogo & Visual & $20 \%$ Nogo & $1-20$ & $\begin{array}{l}\text { ERN, Pe, evoked } \\
\text { theta, intertrial phase } \\
\text { coherence }\end{array}$ \\
\hline $\begin{array}{l}\text { van de } \\
\text { Voorde et al. } \\
2010\end{array}$ & $\mathrm{AD} / \mathrm{HD}^{1}$ & 18 & $\begin{array}{l}\text { Reading Dis. (15), } \\
\text { ADHD+RD (13), } \\
\text { Controls (16) }\end{array}$ & 34 & $\begin{array}{l}\text { DISC- } \\
\text { IV } \\
\end{array}$ & 8-12 & Go-Nogo & Visual & $40 \%$ Nogo & $0.1-30$ & $\begin{array}{l}\mathrm{Ne} / \mathrm{Nc} \text {, early and late } \\
\mathrm{Pe} / \mathrm{Pc}\end{array}$ \\
\hline $\begin{array}{l}\text { van Meel et } \\
\text { al. } 2007\end{array}$ & Com (12), In (4) ${ }^{2}$ & 16 & Control & 16 & $\begin{array}{l}\text { DSM- } \\
\text { IV }\end{array}$ & 8-12 & $\begin{array}{l}\text { Flanker (3 Inter- } \\
\text { trial-intervals) }\end{array}$ & Visual & $\begin{array}{l}50 \% \text { congruent, } \\
\text { incongruent }\end{array}$ & $0.25-40$ & ERN \\
\hline $\begin{array}{l}\text { Albrecht et } \\
\text { al. } 2008\end{array}$ & Com & 68 & $\begin{array}{l}\text { Control (22), Siblings of } \\
\text { ADHD (18) }\end{array}$ & 40 & $\begin{array}{l}\text { DSM- } \\
\text { IV }\end{array}$ & $8-15$ & Flanker & Visual & $\begin{array}{l}50 \% \text { congruent, } \\
\text { incongruent }\end{array}$ & $0.1-15$ & N2, Ne, Pe \\
\hline $\begin{array}{l}\text { Wild-Wall et } \\
\text { al. } 2009\end{array}$ & Com & 15 & $\begin{array}{l}\text { Control (12), Siblings of } \\
\text { ADHD (12) }\end{array}$ & 24 & $\begin{array}{l}\text { DSM- } \\
\text { IV }\end{array}$ & $11-18$ & $\begin{array}{l}\text { Flanker-Nogo } \\
\text { hybrid }\end{array}$ & Visual & $\begin{array}{l}20 \% \text { incongruent, } \\
\text { Nogo }\end{array}$ & $0.1-30$ & $\begin{array}{l}\text { N2, P3a, Ne/Nc, } \\
\text { Pe/Pc }\end{array}$ \\
\hline $\begin{array}{l}\text { Burgio- } \\
\text { Murphy, et } \\
\text { al. } 2007\end{array}$ & Com (96), In (41) & 137 & $\begin{array}{l}\text { Control (29), reading } \\
\text { dis. (29), math dis. ( } 71) \text {, } \\
\text { reading \& maths dis. } \\
\text { (53) }\end{array}$ & 182 & $\begin{array}{l}\text { DISC- } \\
\text { IV }\end{array}$ & 7-13.5 & Oddball & Visual & $\begin{array}{l}\text { Oddball } 117 \% \\
\text { target; oddball } 2 \\
50 \% \text { target }\end{array}$ & $0.1-6$ & ERN, Pe \\
\hline $\begin{array}{l}\text { van Meel et } \\
\text { al. } 2005\end{array}$ & ADHD & 21 & Control & 23 & DISC & $8-12$ & Guessing & Visual & $\begin{array}{l}50 \% \text { correct, } \\
\text { incorrect }\end{array}$ & $0.25-30$ & $\begin{array}{l}\text { FN in ms ranges } \\
150-200,250-300 \text {, } \\
300-350,450-500\end{array}$ \\
\hline
\end{tabular}




\begin{tabular}{|l|l|l|l|l|l|l|l|l|l|}
$\begin{array}{l}\text { Groen et al. } \\
2008\end{array}$ & $\begin{array}{l}\text { Com untreated (18), } \\
\text { Com treated with } \\
\text { medication (17) }\end{array}$ & 35 & Control (18), ASD ${ }^{6}$ (19) & 37 & $\begin{array}{l}\text { DSM- } \\
\text { IV }\end{array}$ & 10-12 & $\begin{array}{l}\text { Probabilistic } \\
\text { Learning }\end{array}$ & Visual & N/A \\
\hline $\begin{array}{l}\text { Holroyd et al. } \\
2008\end{array}$ & Com & 14 & Control & 13 & NS & $8-13$ & Guessing & Visual & $\begin{array}{l}50 \% \text { correct, } \\
\text { incorrect }\end{array}$ \\
\hline $\begin{array}{l}\text { van Meel et } \\
\text { al. 2011 }\end{array}$ & Com (16), In (2) ${ }^{4}$ & 18 & Control & & $\begin{array}{l}\text { DSM- } \\
\text { IV }\end{array}$ & 8-12 & Time estimation & Visual & $\begin{array}{l}50 \% \text { negative } \\
\text { feedback, positive } \\
\text { feedback }\end{array}$ \\
\hline
\end{tabular}

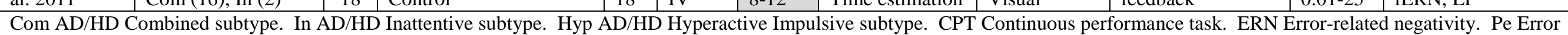

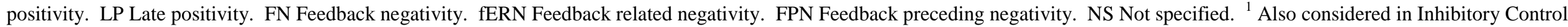

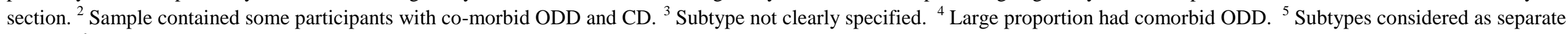
groups. ${ }^{6}$ Autism Spectrum Disorder. 


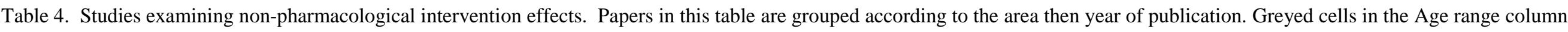
indicate optimal consideration of age.

\begin{tabular}{|c|c|c|c|c|c|c|c|c|c|c|c|c|}
\hline Area & Study & AD/HD type & $\mathbf{N}$ & Other groups & $\mathbf{N}$ & DSM & $\begin{array}{l}\text { Age } \\
\text { range }\end{array}$ & $\begin{array}{l}\text { Task } \\
\text { type }\end{array}$ & Modality & $\begin{array}{l}\text { Stimulus } \\
\text { proportion }\end{array}$ & $\begin{array}{l}\text { Filter } \\
\text { range } \\
(\mathrm{Hz})\end{array}$ & $\begin{array}{l}\text { ERP } \\
\text { components }\end{array}$ \\
\hline $\begin{array}{l}\text { Neurofeedback - } \\
\text { SCP }\end{array}$ & $\begin{array}{l}\text { Heinrich et al. } \\
2004\end{array}$ & Com: training & 13 & Com: waitlist & 9 & $\begin{array}{l}\text { DSM- } \\
\text { IV }\end{array}$ & $7-13$ & CPT & Visual & $10 \%$ Go, Nogo & $0.1-50$ & $\mathrm{CNV}, \mathrm{P} 3$ \\
\hline $\begin{array}{l}\text { Neurofeedback - } \\
\text { Beta }\end{array}$ & $\begin{array}{l}\text { Kropotov et } \\
\text { al. } 2005\end{array}$ & $\begin{array}{l}\text { ADHD }^{1} \text { : good } \\
\text { performers }\end{array}$ & 71 & $\begin{array}{l}\text { ADHD }^{1} \text { : bad } \\
\text { performers }\end{array}$ & 15 & $\begin{array}{l}\text { DSM- } \\
\text { IV }\end{array}$ & $9-14$ & Go-Nogo & Auditory & $50 \%$ Nogo & $0.5-30$ & N1, P2, LC \\
\hline $\begin{array}{l}\text { Neurofeedback - } \\
\text { SCP }\end{array}$ & $\begin{array}{l}\text { Doehnert et al. } \\
2008\end{array}$ & $\begin{array}{l}\text { Com (9), (5) }{ }^{1} \text { : } \\
\text { training }\end{array}$ & 14 & $\begin{array}{l}\text { Com }(8),(4)^{1} \text { : } \\
\text { group therapy }\end{array}$ & 12 & $\begin{array}{l}\text { DSM- } \\
\text { IV }\end{array}$ & $9-12$ & $\mathrm{CPT}$ & Visual & $10 \%$ Go, Nogo & $0.1-30$ & CNV \\
\hline $\begin{array}{l}\text { Neurofeedback - } \\
\text { SCP/Theta }\end{array}$ & $\begin{array}{l}\text { Wangler et al. } \\
2010\end{array}$ & $\begin{array}{l}\text { ADHD }^{1}: \\
\text { Neurofeedback }\end{array}$ & 59 & $\begin{array}{l}\mathrm{ADHD}^{1} \text { : attention } \\
\text { skills training }\end{array}$ & 35 & $\begin{array}{l}\text { DSM- } \\
\text { IV }\end{array}$ & $8-12$ & $\begin{array}{l}\text { Cued } \\
\text { Flanker }\end{array}$ & Visual & $\begin{array}{l}50 \% \\
\text { Incongruent }\end{array}$ & $0.5-30$ & $\mathrm{CNV}, \mathrm{P3}$ \\
\hline Cognitive training & $\begin{array}{l}\text { Johnstone et } \\
\text { al. 2010a }\end{array}$ & $\begin{array}{l}\text { Com: variable } \\
\text { difficulty }\end{array}$ & 18 & $\begin{array}{l}\text { Com: fixed } \\
\text { difficulty }\end{array}$ & 18 & $\begin{array}{l}\text { DSM- } \\
\text { IV }\end{array}$ & $8-12$ & Go-Nogo & Visual & $30 \%$ Nogo & $0.01-30$ & N1, N2, P3 \\
\hline
\end{tabular}

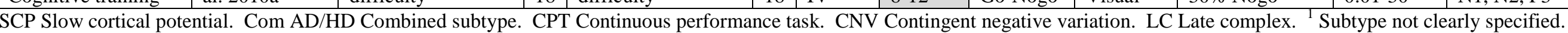




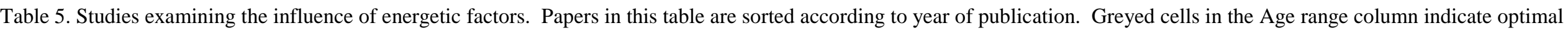
consideration of age.

\begin{tabular}{|c|c|c|c|c|c|c|c|c|c|c|c|}
\hline Study & $\begin{array}{l}\text { AD/HD } \\
\text { type }\end{array}$ & $\mathbf{N}$ & Other groups & $\mathbf{N}$ & DSM & $\begin{array}{l}\text { Age } \\
\text { range }\end{array}$ & Task type & Modality & $\begin{array}{l}\text { Stimulus } \\
\text { proportion }\end{array}$ & $\begin{array}{l}\text { Filter range } \\
\text { (Hz) }\end{array}$ & ERP components \\
\hline Wiersema et al. 2005b & $\mathrm{Com}^{1}$ & 9 & $\begin{array}{l}\text { Control (9), } \\
\text { PKU (9) }\end{array}$ & 18 & $\begin{array}{l}\text { DISC- } \\
\text { IV }\end{array}$ & $7-12$ & Go-Nogo & Visual & $25 \%$ Nogo & $0.1-30$ & N2, P3 \\
\hline Wiersema et al. $2006^{2}$ & $\operatorname{Com}^{1}$ & 22 & Control & 15 & $\begin{array}{l}\text { DISC- } \\
\text { IV }\end{array}$ & $7-13$ & Go-Nogo & Visual & $25 \%$ Nogo & $0.1-30$ & $\mathrm{P} 2, \mathrm{~N} 2, \mathrm{P} 3$ \\
\hline $\begin{array}{l}\text { Benikos and Johnstone } \\
2009\end{array}$ & Com & 18 & Control & 18 & $\begin{array}{l}\text { DSM- } \\
\text { IV }\end{array}$ & $7-14$ & $\begin{array}{l}\text { Cued Go- } \\
\text { Nogo }\end{array}$ & Visual & $30 \%$ Nogo & $0.01-30$ & $\begin{array}{l}\text { Warning/Go/Nogo N1, P2, } \\
\text { N2, P3 }\end{array}$ \\
\hline Johnstone et al. $2010 b^{2}$ & Com & 20 & Control & 20 & $\begin{array}{l}\text { DSM- } \\
\text { IV }\end{array}$ & $7-14$ & Flanker & Visual & 25\% Incongruent & $0.01-30$ & N2a, N2b, P3 \\
\hline
\end{tabular}

Com AD/HD Combined subtype. PKU Phenylketonuria. ${ }^{1}$ Large proportion had comorbid ODD. ${ }^{2}$ Also considered in Inhibitory Control section. 


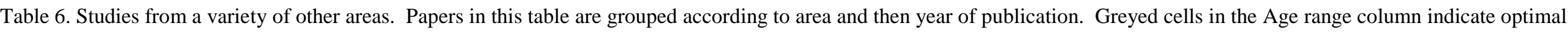
consideration of age.

\begin{tabular}{|c|c|c|c|c|c|c|c|c|c|c|c|c|}
\hline Area & Study & $\begin{array}{l}\text { AD/HD } \\
\text { type }\end{array}$ & $\mathbf{N}$ & Other groups & $\mathbf{N}$ & DSM & $\begin{array}{l}\text { Age } \\
\text { range }\end{array}$ & Task type & Modality & $\begin{array}{l}\text { Stimulus } \\
\text { proportion } \\
\end{array}$ & $\begin{array}{l}\text { Filter } \\
\text { range } \\
(\mathrm{Hz}) \\
\end{array}$ & ERP components \\
\hline $\begin{array}{l}\text { Time- } \\
\text { frequency }\end{array}$ & $\begin{array}{l}\text { Johnstone et al. } \\
2003\end{array}$ & $\begin{array}{l}\text { Com (30), } \\
\text { In }(30)^{1}\end{array}$ & 60 & Control & 30 & $\begin{array}{l}\text { DSM- } \\
\text { IV }\end{array}$ & $\begin{array}{l}8-18(3 \\
\text { groups) }\end{array}$ & Oddball & Auditory & $15 \%$ target & $\begin{array}{l}0.01-12 \\
0.01-2\end{array}$ & $\begin{array}{l}\text { Raw: N1, P2, N2, P3; } \\
\text { SW: ENSW, LPSW }\end{array}$ \\
\hline $\begin{array}{l}\text { Time- } \\
\text { frequency }\end{array}$ & $\begin{array}{l}\text { Yordanova et al. } \\
2006\end{array}$ & ADHD & 14 & $\begin{array}{l}\text { Control (14), } \\
\text { TD (14), TD + } \\
\text { ADHD (11) }\end{array}$ & 39 & $\begin{array}{l}\text { DSM- } \\
\text { III-R }\end{array}$ & $9-13$ & $\begin{array}{l}\text { Selective } \\
\text { attention }\end{array}$ & Auditory & $40 \%$ target & 3.0-7.5 & $\begin{array}{l}\text { Early theta response, } \\
\text { late theta response }\end{array}$ \\
\hline $\begin{array}{l}\text { Time- } \\
\text { frequency }\end{array}$ & Lenz et al. 2008 & $\begin{array}{l}\text { Com (10), } \\
\text { In (3) }\end{array}$ & $13^{3}$ & Control & 13 & $\begin{array}{l}\text { DSM- } \\
\text { IV }\end{array}$ & $11-15$ & $\begin{array}{l}\text { Recognition } \\
\text { memory }\end{array}$ & Visual & N/A & $30-80$ & $\begin{array}{l}\text { Individual peak } \\
\text { frequency in 30-80 } \\
\mathrm{Hz}\end{array}$ \\
\hline $\begin{array}{l}\text { Time- } \\
\text { frequency }\end{array}$ & Lenz et al. 2010 & $\begin{array}{l}\text { Com (8), In } \\
\text { (5) }\end{array}$ & $13^{3}$ & Control & 13 & $\begin{array}{l}\text { DSM- } \\
\text { IV }\end{array}$ & $11-17$ & $\begin{array}{l}\text { Forced-choice } \\
\text { reaction time } \\
\text { memory }\end{array}$ & Visual & N/A & $30-80$ & $\begin{array}{l}\text { Individual peak } \\
\text { frequency in 30-80 } \\
\text { Hz, P1, N1, P2, FN }\end{array}$ \\
\hline Memory & $\begin{array}{l}\text { Krauel et al. } \\
2009\end{array}$ & $\begin{array}{l}\text { Com (14), } \\
\text { In (4) }\end{array}$ & 18 & Control & 15 & $\begin{array}{l}\text { DSM- } \\
\text { IV }\end{array}$ & NS & Memory & Visual & N/A & $0.01-70$ & P300 \\
\hline Diagnosis & $\begin{array}{l}\text { Smith et al. } \\
2003\end{array}$ & $\begin{array}{l}\text { Com (50), } \\
\text { In (50) } \\
\end{array}$ & 100 & Control & 50 & $\begin{array}{l}\text { DSM- } \\
\text { IV } \\
\end{array}$ & $\begin{array}{l}8-18(2 \\
\text { groups) }\end{array}$ & Oddball & Auditory & $15 \%$ target & $0.01-30$ & $\mathrm{~N} 1, \mathrm{P} 2, \mathrm{~N} 2, \mathrm{P} 3$ \\
\hline Preparation & $\begin{array}{l}\text { Banaschewski } \\
\text { et al. } 2008\end{array}$ & Com & 15 & Control & 16 & $\begin{array}{l}\text { ICD- } \\
10\end{array}$ & $9-12$ & CPT & Visual & $\begin{array}{l}10 \% \text { Go, Nogo, } \\
\text { Neutral }\end{array}$ & $0.1-50$ & $\begin{array}{l}\mathrm{CNV} \text { in } 3 \text { time } \\
\text { windows }\end{array}$ \\
\hline Emotion & $\begin{array}{l}\text { Williams et al. } \\
2008\end{array}$ & $\mathrm{ADHD}^{2}$ & 51 & Control & 51 & $\begin{array}{l}\text { DSM- } \\
\text { IV }\end{array}$ & $8-17$ & Emotional faces & Visual & Equal & NS & $\begin{array}{l}\text { P120, N170, P3, } \\
\text { N120, VPP, N3 }\end{array}$ \\
\hline
\end{tabular}

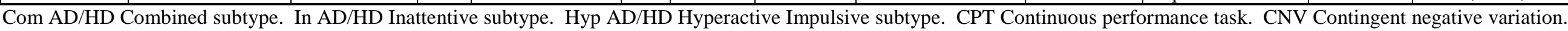

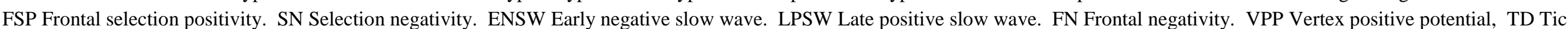

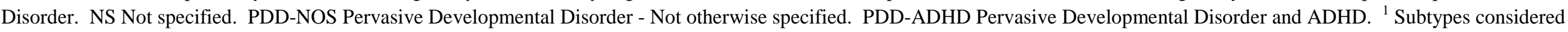

as separate groups. ${ }^{2}$ Subtype not clearly specified. ${ }^{3}$ Sample contained some participants with co-morbid ODD and CD. 